\title{
Army Attack Aviation and Joint Air Operations: Doctrinal and Institutional Barriers
}

\author{
A Monograph \\ By \\ Major Sharon L. Holmes \\ United States Air Force
}

School of Advanced Military Studies

United States Army Command and General Staff

College

Fort Leavenworth, Kansas

First Term AY 99-00

Approved for Public Release; Distribution is Unlimited DIC QUALITY INSPECTED 3

20000321045 


\title{
SCHOOL OF ADVANCED MILITARY STUDIES MONOGRAPH APPROVAL
}

\author{
Major Sharon L. Holmes
}

Title of Monograph: Army Attack Aviation and Joint Air Operations:

Doctrinal and Institutional Barriers

Approved by:

Monograph Director

COL (S) Kim L. Summers, MBA

Director, School of Advanced

COL Robin P. Swan, MMAS

Military Studies

Director, Graduate Degree

Phillip J. Brookes, Ph. D.

Program

Accepted this $7^{\text {th }}$ Day of January 2000 


\title{
ABSTRACT
}

\author{
ARMY ATTACK AVIATION AND JOINT AIR INTEGRATION: DOCTRINAL \\ AND INSTITUTIONAL BARRIERS by Major Sharon L. Holmes, USAF, 55 pages.
}

Less than ten years after opening the Gulf War Air campaign, Army Attack

Aviation was propelled into the spotlight over a perceived failure to support the North Atlantic Treaty Organization air operations in the Serbian province of Kosovo. Since political constraints precluded a ground option to resolve the conflict, the Supreme Allied Commander, Europe requested a wide range of aerospace assets to accomplish campaign objectives. When adverse weather impacted fixed-wing operations, Army Attack Aviation under the command structure of Task Force Hawk was deployed to Albania to answer the shortfall. Operation ALLIED FORCE ceased air operations without ever committing Task Force Hawk on 24 June 1999, when Serbian President Milosevic agreed to withdraw all Serbian military and police forces from Kosovo.

Although Task Force Hawk was never employed in air strikes in Kosovo, the Air War Over Serbia in March - June 1999 highlighted some underlying doctrinal and institutional barriers to integrating Army Attack Aviation into joint air operations. Doctrinally, the United States Army was ill-prepared to operate Army Attack Aviation as an air weapon. There were no doctrinal constructs to integrate Corps staffs at the operational level. Absence of an official command relationship between the Combined Forces Air Component Commander and the Task Force Hawk Commander further exasperated the integration of Army Attack Aviation into Joint Air Operations. The battlefield framework of deep, close, and rear operations was not applicable to the combined air operations environment in the Air War Over Serbia. Instead, the Joint Air Doctrine environment conducts operations based on air mission elements like Strategic Attack, Air Interdiction and Close Air Support. Institutionally, mistrust between USA and Joint Air Operations leadership and planners, lack of understanding of integration requirements, fear of loss of control of Army Aviation, and training constructs adversely impacted the integration of Army Attack Aviation in Operation Allied Force.

The intent of this monograph is to explore the doctrinal and institutional barriers to integration of Army Attack Aviation into Joint Air Operations. The author uses the historical records of Operation Desert Storm and the preliminary After Action Reviews of Operation Allied Force as a basis to evaluate the doctrine. Additionally, the author compares Army Doctrine and Joint Doctrine to establish complementary and disparate elements.

The study concludes that integrating USA Attack Aviation into joint air operations is the right idea given the proper time to define the doctrine, educate the force, and train the staffs and aviators. The doctrinal and institutional barriers can be resolved with the concerted effort of USA and Joint Air Operations planners, aviators, and leaders to broaden perspectives and establish habitual relationships in doctrine development and training. 


\section{TABLE OF CONTENTS}

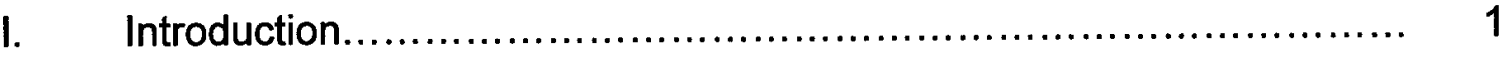

II. A Case of Night and Day-Army Aviation in Operation Desert Storm and Allied Force............................................................ 6

III. Doctrinal and Theoretical Underpinnings for Army Attack Aviation Employment and Joint Air Integration................................. 15

IV. The Opposing Views of Integrating USA Attack Aviation into Joint Air Operations.............................................................. 24

V. Final Analysis and Integration Recommendations..................... 36

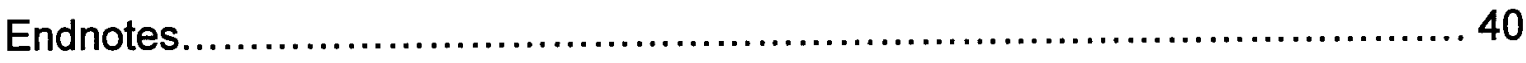

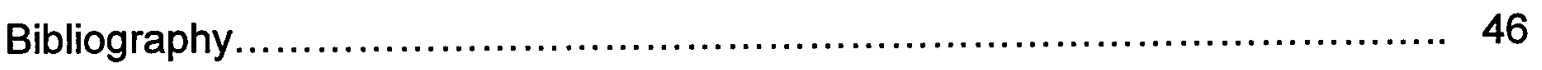

\section{CHAPTER 1 INTRODUCTION}


What you really want to do is, if you're going to do an Apache operation against a target-let's take a Kosovo operation--the subordinate commander in Kosovo is not the ground commander. He is supporting the JFACC and that should be his role. The JFACC should determine what the Apache targets are as a result of the entire responsibility he has in conducting that air campaign. And then he sets up for those Apaches.

GEN Jack Keane, Vice Chief USA

Inside the Army, 17 May 1999

Air operations in Kosovo recently highlighted some underlying difficulties of integrating Army Attack Aviation into joint air operations. U.S. public expectations of rapid military responsiveness surrounded Task Force Hawk's deployment to Albania, in support of the North Atlantic Treaty Organization (NATO) ongoing Air War Over Serbia (AWOS). With limited resources available to fulfill the needs of theater commanders, Commanders-in-Chief (CINCs) and Joint Force Commanders (JFCs) require multiple, varied effects within the battle space to achieve theater and national objectives. Operations in Kosovo revealed some shortfalls in adverse weather air power capability where conventional fixed-wing air were not the best weapon to combat the target. Task Force Hawk's mission was to cover the additional requirements of the selected NATO strategy, which fixed-wing assets did not cover. ${ }^{1}$ Where the operational environment, weather, and terrain minimize the advantages of fixed-wing air, Army Attack Aviation might supply the critical capability to accomplish theater objectives. If doctrinal and institutional barriers exist which prevent applying Army Attack Aviation against the obstacle to mission success (enemy center of gravity or COG), these barriers must be examined and mitigated. ${ }^{2}$

In the 1991 Gulf War, the Pentagon, news anchors, and retired military officers applauded the military services for breaking down barriers in the Air Campaign to achieve the 
operational military aim. The Gulf War Air Power Survey (GWAPS) identified these images and impressions as falsehoods. ${ }^{3}$ The overwhelming numbers of air assets permitted all services to participate in the Gulf War without truly integrating all forces into a cohesive, centrally organized joint air fighting team. General Bernard Trainor reinforced the GWAPS finding in his book, The General's War. He criticized the Air Campaign for the limited focus on US Army Corps targets that resulted in limited destruction of Republican Guard forces. With an integrated joint air operation in the Gulf War, perhaps the effects against the Republican Guard forces would have been greater and Iraq's threat to the region diminished even further.

Less than ten years after opening the Gulf War Air Campaign, Army Attack Aviation was propelled into the spotlight over a perceived failure to support NATO air operations in the Serbian province of Kosovo. Accusations from Air Force and Army officers regarding the unwillingness or unpreparedness of the other to integrate as a joint team leaves many asking what the proper role of Army Attack Aviation is in the joint air operational environment. The lack of integration with joint air operations and operational shortfalls of Operation ALLIED FORCE marked the columns of national newspapers and consumed the Pentagon, news anchors, and retired military officers in a search to discover what happened. A July 16, 1999 article in the Baltimore Sun carried the headline "Army Hunts For Answers As Apaches Fail In Kosovo." General Eric Shinseki, the Army Chief of Staff stated "'we (the USA) are not broken, but we need to pay attention to some of the things we learned out of this (Kosovo)."'6 He identified institutional barriers within the categories of readiness, training, leadership development and resource allocation as issues from Task Force Hawk in the AWOS.

General Shinseki identified institutional barriers that prevented Task Force Hawk's success in the AWOS. This monograph evaluates the doctrinal and institutional barriers General Shinseki highlights, which allowed Army Attack Aviation assets to deploy to Kosovo and operate in an environment where operational military success was assumed but not fully 
delivered $?^{7}$ One doctrinal barrier to integration deals with the divergent USA and Joint doctrine view of Attack Aviation's role in joint air operations. The Joint Electronic Dictionary defines joint air operations as air operations performed with air capabilities/forces made available by components in support of the joint force commander's operation or campaign objectives, or in support of other components of the joint force. USA doctrine does not consider Attack Aviation as an air asset, instead reinforces the sole role as a ground maneuver element, irrespective of the operational environment. As a professional force of military officers and aviators, we are committed to the solemn oath to support and defend the Constitution, including Title $X$. Title $X$ charges the Military Services to recruit, train, equip, and provide forces to the war fighting CINCs who fight as a joint war fighting team. Within the context of meeting theater requirements, building integrated joint air power capabilities is not a bridge too far or a problem too hard to solve.

Although integrated joint air power capabilities are required to fulfill CINC requirements, the solutions for eliminating doctrinal and institutional barriers are neither easy nor quick. The Army's aviation leaders and Air Force officer's who work with the Army can clarify solutions to resolve the barriers. However, simply understanding the advantages and barriers to joint air operations does not mean the practice permeates to the front line forces or battalion and squadron commanders who must make joint air operations integration work. There must be some common ground for the USA and USAF, through joint doctrine and joint training, to resolve the barriers that prevent simultaneous integration of Army Attack Aviation into joint air and land component operations, or independent air operations supporting a joint air campaign.

The military objective remains the same for air-only and joint air-ground campaigns-produce effects, attack decisive points, and achieve military aims of the joint force 
commander. Acknowledging the current political climate where domestic issues continue to diminish the appetite for expanding military budgets, integration of Army Attack Aviation into joint air operations must be fiscally prudent and operationally achievable. The process requires a long-term commitment from military officers and aviators from every Service. With total integration of the appropriate joint air assets, the air campaign will be better able to produce effects across the full spectrum of targets, including adverse weather environments.

\section{METHODOLOGY}

In order to identify the institutional and doctrinal barriers to USA Attack Aviation integration into joint air operations, the monograph attempts to balance the actual tactical and operational employment record with Service and Joint doctrine. In Chapter 2, the researcher reviewed the employment record of Army Attack Aviation in Operation DESERT STORM. The Gulf War Air Power Survey and various afteraction reports and books served as sources to reveal the role of USA Attack Aviation in support of the Air Component and Land Component. Next, Chapter 2 reviewed the open source information regarding the employment of Task Force Hawk for operations in Kosovo. Anthony Cordesman's report on Kosovo Lessons Learned, military periodicals, and interviews served as sources to reveal the potential role of USA Attack Aviation in the Combined Air Operations. The potential role of Task Force Hawk is explored since Serbian President Milosevic agreed to NATO demands prior to Task Force Hawk's employment. Joint air operations in OPERATION DESERT STORM and OPERATION ALLIED FORCE served as the historical backdrops for evaluating Army Attack Aviation integration into joint air operations.

One primary objective was identifying where integrated air power capability enhanced the operational commander's ability to achieve military objectives. The primary 
outcome was to answer why Army Attack Aviation should be a part of joint air operations.

After reviewing the historical backdrop of Operations DESERT STORM and ALLIED FORCE, the monograph evaluated doctrine in Chapter 3. Chapter 3 opened with a look at USA doctrine. Field Manual 1-112 and Training and Doctrine Pamphlets 525-5 and 525-80 served as the foundation for the doctrinal review of USA Attack Aviation roles and employment methods. Chapter 3 also evaluated the requirements for integrating air power capabilities in Joint doctrine. Joint Publications $3-0,3-56.1$, and 5.0 served as the foundation for joint integration. Finally, Chapter 3 examined the complementary and divergent issues between Army and Joint doctrine.

The doctrinal review and evaluation served as the focal point for reflections by USAF and USA officers on the institutional and doctrinal barriers to USA Attack Aviation integration into joint air operations. Chapter 4 summarized responses to four questions:

1. Do you feel Army Attack Aviation has a role in joint air operations?

2. What are the top three barriers you perceive to integrating Army Attack Aviation into joint air operations?

3. Do you view the source of barriers to integrating Army Attack Aviation into joint air operations as doctrinally or institutionally-based?

4. Can these barriers be resolved? 
The key outcome of the interviews answered the question, "are there barriers to the integration required to make joint air operations the practical reality and the standard practice?" These interviews revealed some of the factors at the foundation of this disconnect in what the nation and theater CINCs require, the Chairman of the Joint Chiefs of Staff promise, and the U.S. military delivers.

With tactical and operational employment methods and the doctrinal review as the yardstick for integrating air power capabilities, Chapter 5 analyzed the barriers identified by the USAF and USA officers. The objective remained to answer the fundamental question, can the institutional and doctrinal barriers to integration be resolved? Chapter 5 concluded with recommendations for interim and long-term solutions and areas for future study.

If the current trend of diminishing military budgets and increasing military requirements continue, excluding such a capable force (Army Attack Aviation) from joint air operations may incur negative repercussions for the joint force commander's plans, execution, and achievement of military aims. Shortfalls exist that conventional fixed-wing aircraft cannot completely combat. Army Attack Aviation should be prepared to operate as a separate entity within the joint air operations environment while interacting with the process that connects all the moving parts into a coherent joint fighting team.

\section{CHAPTER 2 A CASE OF NIGHT AND DAY - ARMY AVIATION IN OPERATION DESERT STORM AND ALLIED FORCE}


Although total integration of USA Attack Aviation into the joint air operations environment was in its infancy during DESERT STORM, today's military planners benefit from a closer review of the historical employment record. What were the conditions, which gave CENTCOM operational planners, the unorthodox idea of integrating Army Attack Aviation into initial strikes on radar sites in OPERATION DESERT STORM? In DESERT STORM, the campaign design initially postured friendly forces in a defensive array to husband sufficient combat power to launch a major ground offensive. The campaign's four phases were the strategic air campaign, KTO (Kuwaiti Theater of Operations) air supremacy, destruction of enemy ground forces in the KTO, and the ground attack. The air campaign worked concurrently with the ground campaign to set the conditions for conflict termination, and independently to cause strategic effects.

The operational joint air environment of DESERT STORM concentrated assets against targets in the KTO and within Iraq. The principal target categories for the air campaign during the first three operational campaign phases included:

1. Strategic air defense

2. Command, control, and communication or $\mathrm{C} 3$ (telecom)

3. Military support (Republican Guard forces)

4. Scuds

5. Nuclear biological chemical agents (NBC)

6. Surface to air missiles (SAMs) in KTO

7. Electricity and Oil

8. Transportation infrastructure (airfields, ports, railroads). ${ }^{10}$

The predominant focus of the air campaign, based on JFC guidance, were targets in Iraq and the Republican Guard forces in the KTO. The most likely integration of USA Attack Aviation assets within JFC guidance was Republican Guard forces in the KTO and additional target categories in close proximity to the Saudi-Kuwaiti border. These target selection refinements made the most sense based 
on staging, range, and survivability considerations. Opening air strikes in DESERT STORM packaged USA Attack Aviation (Apache Helicopters) with Air Force Special Operations Command (AFSOC) MH-53 Pave-Low Helicopters in an 0239 attack on two Iraqi early warning sites on the frontier. ${ }^{11}$ This integrated USA-USAF rotary-wing strike package destroyed Iraqi early warning sites and cleared a corridor for at least three strike packages attacking Scud sites and mobile Scud launchers, and jamming (disrupting) electronic systems. After this skillfully crafted opening integration into joint air operations, USA Attack Aviation reverted back to the XVIII Airborne Corps.

During the subsequent campaign phases (II-KTO air supremacy and III-destruction of enemy ground forces in KTO) of DESERT STORM, there is little evidence detailing integration of Army Attack Aviation into the air campaign. The weather turned poor with a 33 percent increase in targets obscured by clouds hampering full-scale, fixed-wing operations. ${ }^{12}$ Fixed wing missions were conducted at medium altitude $8,000-12,000$ feet to protect aircrews from antiaircraft artillery (AAA) defenses. The increase in altitude, coupled with target obscuration greatly slowed the timeline for attriting Iraqi ground forces by 50 percent. Attriting Iraqi ground forces in KTO by 50 percent was a key air campaign objective, and precursor to the operational campaign's final phase, the ground attack. While fixed-wing operations continued at medium altitude, USA Attack Aviation conducted low-level operations under the umbrella of organic suppression of enemy air defense systems within the XVIII and VII Corps Areas of Operation. The dangers of the AAA threat not withstanding, were USA Attack Aviation assets the proper fit for preparing the battle space to meet the Joint Force Commander (JFC) requirements and time line?

During the two-week period of adverse weather, Aviation Brigades were perhaps the most likely candidates to properly decipher and execute the JFC, GEN Norman Schwarzkopf's, intent. GEN Schwarzkopf tasked the air component to attrit 50 percent of the Iraqi ground forces. Specifically, USA Attack Aviation was equipped to attack tanks, armored personnel carriers, and artillery within range $(100-150 \mathrm{~km})$ of the FARP (forward arming and 
refueling point) sites. The GWAPS summary report indicated that only helicopters could operate successfully due to low ceilings from weather, blowing sand or oil well fires. ${ }^{13}$ Since USA Attack Aviation was not incorporated into the Air Tasking Order (ATO), the GWAPS was unable to capture the number of sorties executed by rotary-wing assets to properly portray their impact on the air objective to attrit 50 percent of the Iraqi ground forces. Planning restrictions set by GEN Schwartzkopf sought to protect the disposition of coalition ground forces prior to the anticipated envelopment maneuver. Misperception of the JFC's planning guidance could partially explain the total absence of attack aviation in deep attacks to attrit Iraqi forces and prepare the battle space during campaign phases I - III.

Major Carpenter, in his research entitled Effect Of Command Relationships On Joint Operations In The Gulf War, alluded to misperceptions of JFC guidance coupled with a strict adherence to service doctrine over joint mission accomplishment in the employment of USA Attack Aviation. Major Carpenter indicated the integration issue was almost a forbidden conversation between the Battlefield Coordination Element (BCE) and the JFACC planning staff, often preventing consideration of capable assets to eliminate key maneuver threats to the impending ground campaign. ${ }^{14}$ Doctrinal and institutional issues or barriers to USA Attack Aviation integration into joint air operations are evaluated further in subsequent chapters. Within the framework of the operational campaign design, what unique capabilities did USA Attack Aviation employ to enhance the joint team or fulfill joint force commander requirements?

\section{ARMY ATTACK AVIATION IN OPERATION DESERT STORM}

John Warden in his book The Air Campaign stressed the fact, no force has achieved victory without first establishing air superiority, not through air forces alone but through the combined efforts of naval and ground forces. ${ }^{15}$ The opening night DESERT STORM air strike on radar sites by the Apache-Pave Low strike package demonstrated USA Aviation's 
capability to operate within a joint framework to support air campaign objectives. What additional capability did USA Attack Aviation provide in DESERT STORM?

General Crosbie E. Saint, CINCUSAREUR, served as a force provider for Desert Storm and resourced Army forces, and specifically Army Aviation based on Air-Land Battle doctrine, the capable corps concepts, and USCENTCOM campaign plans. ${ }^{16}$ The capable corps concepts "stressed vast areas of operations (AO), long and fast marches, maneuver skills, meeting engagements, and massed firepower;" and set the framework for training, modernizing, and employing USAREUR forces in DESERT STORM. ${ }^{17}$ General Saint was a great advocate of AirLand Battle, often proposing concepts for attack aviation deep attacks to support his capable corps concepts, and was first to employ Apache attack helicopters in night operations. ${ }^{18}$ The Army Aviation forces were predisposed by capable corps training concepts to focus efforts and plan operations within a specific ground-centric mindset, which partially excluded time, resources, and effort in an air-focused campaign.

A brief description defining the deep, close, rear battlefield architecture follows to facilitate doctrinal clarity on terminology. Field Manual (FM) 100-5, Operations describes the battlefield framework or architecture in terms of deep, close, rear terminology to order the territory into manageable areas for operations, reconnaissance, command and control, and sustainment and provide a greater understanding of time-space relationships. Deep operations "attack enemy functions like command centers, logistics, and air defense while simultaneously destroying combat forces." ${ }^{19}$ Deep operations "are executed with fires, maneuver, and leadership against enemy forces and functions beyond the close battle. ${ }^{120}$ Close operations involve forces "in immediate contact with the enemy in the offense or defense and are the Corps and Division current battles. ${ }^{.21}$ Rear operations "assist in providing freedom of action and continuity of operations, logistics, and battle command and exist to sustain the current close and deep fights and posture forces for future operations. ${ }^{22}$ Joint aerospace doctrine does not differentiate the battlefield into a deep, close, rear 
framework; instead the battle space is approached from the aspect of the missions occurring and the relationship to theater objectives. The deep, close, rear battlefield framework was integral to the entire operational framework for all USA operations including Attack Aviation operations in DESERT STORM, and served as the frame of reference for integration and coordination with joint air operations.

Based on the train-as-you-fight methodology pervasive among the U.S. military force, how were USA Attack Aviation employed in DESERT STORM? The $101^{\text {st }}$ Airborne Division executed the first-ever heliborne movement of a Brigade 93 miles into Iraq and commenced a follow-on mission $90+$ miles deeper into Iraqi territory to cut Highway 8 , the line of retreat west from the theater. ${ }^{23} 4^{\text {th }}$ Brigade, $1^{\text {st }}$ Armored Division $\left(1^{\text {st }}\right.$ AD) started DESERT STORM with one battalion OPCON (under operational control) of the $2^{\text {nd }}$ Armored Cavalry Regiment (ACR) allowing 24 hour a day attack operations. These 24 hour a day attack operations focused on the close fight initially (during phase IV-ground attack operations), destroying maneuver and artillery groupings $15-20 \mathrm{~km}$ ahead of the $1^{\text {st }} \mathrm{AD}$ lead Brigades.

Additionally, 4th Brigade's Task Force Phoenix (TFP) integrated UH-60 general support with Black Hawk companies. TFP's tasks included all medium lift missions, Special Forces extraction (some $130 \mathrm{~km}$ from UH-60 staging areas), FARP emplacements (often 80 $\mathrm{km}$ from the objective area), and command and control (C2) missions in the $1^{\text {st }}$ AD sector. ${ }^{24}$ The USA aviators were fully integrated into the ground campaign deep operations and admirably achieved Division and ground component objectives. Major General Ronald Griffith, Commanding General $1^{\text {st }}$ AD during DESERT STORM, cited the integration of VII Corps Apaches and USAF tactical air elements in attacking and destroying enemy remnants. ${ }^{25}$ Deep operation attacks during the final two days of the war included multibattalion attacks against retreating ground forces, and accounted for considerable destruction of Iraqi offensive capability. 


\section{POST DESERT STORM JOINT INTEGRATION ASSESSMENTS}

Operation DESERT STORM was a resounding success in the air and on the ground

for coalition and U.S. forces. Despite the great successes, the U.S. military identified areas warranting improvement. Joint integration of available assets was one of those lessons.

Prior to DESERT STORM, Col. John Warden warned joint warfighters and planners "to bring elements of air power together into a coherent fighting organization" only after three specific conditions were met. Col. Warden identified extensive peacetime training, full knowledge of the $\mathrm{C} 2$ systems up and down the chain of command, and complete disclosure of pertinent information at the lower echelons to execute the plan as prerequisites to joint integration. ${ }^{26}$ Often, conflict compels warfighters to accelerate integration efforts and exercise initiative. The opening night of the air campaign was strong evidence of such accelerated integration, however, competing demands on limited air assets (such as USA Attack Aviation) precluded repeat performances. The GWAPS team appropriately concluded "neither the Air Force nor Army fully developed a methodology for attacking ground forces from the air," and lacked a coherent capability to accurately strike and assess bomb damage assessment (BDA) ${ }^{27}$ The joint failure of U.S. military leaders and planners to design a comprehensive air-ground attack methodology would return to haunt U.S. forces within ten years over Kosovo in Operation ALLIED FORCE.

\section{TASK FORCE HAWK AND THE AIR WAR OVER SERBIA}

In March through early June 1999, the North Atlantic Treaty Organization (NATO) conducted air offensive operations in the Yugoslavian Republic of Serbia and Serbian province of Kosovo in response to ethnic cleansing initiated by Serbian military and police forces. The NATO consensus agreed an air-only campaign would achieve objectives, NATO consensus for ground forces in a non-permissive environment did not exist. ${ }^{28}$ Operation 
ALLIED FORCE campaign strategy summarized by General Henry H. Shelton, Chairman of the Joint Chiefs of Staff (CJCS) comprised three phases:

1) Phase One - set the conditions for the campaign by targeting VJ/MUP leadership, sustainment and the integrated air defense system (IADS).

2) Phase Two - isolated Serbian forces, increased the intensity of the campaign, targeted road and bridge networks, petroleum refineries, storage and distribution, and command, control and communication (C3).

3) Phase Three - targeted industry, electrical power grids, and forces in the field. Milosevic agreed to cease hostilities, withdrew from Kosovo, and permitted a NATO Peace Keeping force in Kosovo prior to the full implementation of Phase Three. ${ }^{29}$

Based on a NATO air-only campaign strategy, Lieutenant General Michael Short, the Combined Forces Air Component Commander (CFACC) served as the supported commander to achieve campaign objectives. ${ }^{30}$ The air campaign planning staff was relatively free to conduct operational planning based on integrating all available U.S. and NATO military assets into a cohesive warfighting team. Due to a fundamental disagreement over the COG between the Supreme Allied Commander EUROPE (SACEUR), General Wesley Clark (COG - Serbian $3^{\text {rd }}$ Army in Kosovo) and the CFACC (COG - key facilities and sources of power in Serbia), rotary-wing assets were not considered initially as a viable participant in an air-only campaign. ${ }^{31}$ Once the SACEUR convinced the JCS to deploy V Corps and her subordinate Aviation units under the command structure of Task Force Hawk, military campaign planners started the planning process to integrate these assets into operations against the Serbian $3^{\text {rd }}$ Army in Kosovo.

What factors influenced SACEUR's decision to request USA Aviation (Task Force Hawk) assets to prosecute the NATO air-only campaign against the Serbian $3^{\text {rd }}$ Army in Kosovo? The Air Campaign started on 24 March 1999 and Task Force Hawk started to move on or about 10 May 1999. One of the key factors, which impacted SACEUR's request for USA Aviation, was the weather impact on the air campaign. ${ }^{32}$ Anthony Cordesman, an 
independent researcher and compiler of lessons and non-lessons of the NATO Air and Missile Campaign in Kosovo highlights the impact of weather on the air campaign. Anthony Cordesman assessed only seven days in the first twenty-one days as favorable, recording ten days where fifty per cent of the strike sorties were canceled. Overall weather impacts on the 78-day air campaign totaled 39 days, where 50 percent of the strike sorties were canceled. ${ }^{33}$ Most of the targets attacked during this twenty-one day adverse weather period were in the vicinity of Belgrade while little to no targets in Kosovo were attacked. The media appeared relentless in their assaults on the Pentagon briefer for the military's apparent inability to impact the Serbian $3^{\text {rd }}$ Army in Kosovo. Another crucial factor for requesting USA Aviation assets stemmed from the constant stream of news clips from late March - May 1999 of refugees pouring across the borders of Macedonia, Albania, and Montenegro. ${ }^{34}$ The international outcry to do something to stop the ethnic cleansing was overwhelming. Reports on the evening news showed refugee and internally displaced persons at close to one million and demanded retribution.

Faced with the adverse weather impacts and the overwhelming refugee flow, SACEUR anxiously awaited Task Force Hawk's arrival in the theater. Task Force Hawk was seen as an answer to the Serbian $3^{\text {rd }}$ Army problem, a flexible low-flying asset capable of getting below the low cloud layers, identifying Serbian tanks and artillery, and attacking dispersed enemy ground elements. The CFACC, LT GEN Short was convinced the COG was not the Serbian $3^{\text {rd }}$ Army and was unwilling to place any air assets at risk in Kosovo to attack dispersed forces. ${ }^{35}$ Additionally, command and control relationships were strained between the Deep Operations Coordination Cell (DOCC) and the Combined Air Operations Center (CAOC). A breakdown occurred between the DOCC and the CAOC regarding the supported and supporting relationship. ${ }^{36}$ Controversy arose over integration of Task Force Hawk assets on the Air Tasking Order (ATO), the air operations record. An official command relationship was never established between TF Hawk and the CFACC. ${ }^{37}$ With the extreme 
difficulty encountered in attempting to integrate USA Aviation into joint air operations, training accidents, and CFACC and V Corps reservations to commit Task Force Hawk, the barriers were simply to great to overcome. Operation ALLIED FORCE ceased air operations without ever committing Task Force Hawk on 24 June 1999, when Serbian President Milosevic agreed to withdraw all Serbian military and police forces from Kosovo.

\section{CHAPTER 3 DOCTRINAL AND THEORETICAL UNDERPINNINGS FOR ARMY ATTACK AVIATION EMPLOYMENT AND JOINT AIR INTEGRATION}

What changing doctrinal and theoretical conditions, from 1991 to 1999 , precluded Operation Allied Force air campaign planners from integrating Army Attack Aviation into joint air operations? A review of Service doctrine should clarify the Army's view of joint integration of attack aviation. FM 1-112, Attack Helicopter Operations, TRADOC Pamphlet 525-5, Force XXI Operations, and TRADOC Pamphlet 525-80, Army Aviation Warfighting Concept of Operations serve as the doctrinal manuals for review of USA Attack Aviation employment.

\section{SERVICE DOCTRINE REVIEW}

Attack helicopter battalions (ATKHB) assigned to Division Aviation Brigades and Corps provide the supported, ground commander a highly mobile and lethal

armor, personnel, and material destruction capability during the day and night. ${ }^{38} \mathrm{FM}$ 1-112 stresses the point that an ATKHB never fights alone, instead the fighting unit coordinates with other maneuver, combat support, combat service support, and joint 
forces to form a combined arms team. Nine employment options are identified for Attack Aviation in combat operations:

1. Attack massed armored or light forces

2. Attack in depth to extend influence of force

3. Dominate avenues of approach

4. Reinforce ground forces by fire

5. Mass to defeat enemy penetrations

6. Attack to protect flanks of moving or halted friendly main body and passage of lines

7. Provide security for movement by ground forces

8. Conduct reconnaissance

9. Perform search and attack missions ${ }^{39}$

Fifty percent of these employment options are compatible within an air-only or airground campaign and, therefore compatible for joint air integration. FM 1-112 acknowledges an attack aviation weakness against enemy forces in prepared, wellcamouflaged positions and the inability to conduct missions that require the permanent occupation of terrain. ${ }^{40}$ In military operations in Kosovo, the tactical environment was not conducive to the strengths of the ATKHB, although the mission was within the doctrinal employment options. ${ }^{41}$ USA Attack Aviation's role as a maneuver force enhances the ground commander's plan by shaping the battlefield 
through deep operations, identifying lucrative targets of opportunity, and destroying massed, moving targets.

The TRADOC Pamphlets concentrate on the future employment of USA Attack Aviation in the $21^{\text {st }}$ century. TRADOC Pam 525-5 stresses the idea of depth and simultaneous attack "to directly influence the enemy throughout the width, height, and depth of his battle space to stun, then rapidly defeat an enemy. ${ }^{n 42}$ USA Attack Aviation is a key component to the joint ground campaign under this concept. Additionally, the capability of Army aviation assets to self-deploy was identified as a major contributor to the JFC's early entry capability. Although TRADOC Pam 525-5 asserts the capability of USA Aviation to self-deploy, the $300 \mathrm{KM}$ combat radius of AH-64 helicopters, with fuel tanks, limits or precludes long-range deployment without multiple refueling stops. The self-deploy assertions also ignores other Service doctrine mandating that Attack Aviation will not employ as a single entity, but part of a combined arms team. Without the accompanying fire support, force protection, and command infrastructure required by FM 1-112, the self-deployable USA Attack Aviation still remains incapable of employment according to Service doctrine.

TRADOC Pam 525-80 claims to link and integrate overarching concepts from TRADOC Pam 525-5 into aviation Future Operational Capability determination. The pamphlet identifies "aviation's strength in its continual ability to deploy quickly, conduct reconnaissance and security, maneuver rapidly, and focus tremendous combat power for the land component commander." ${ }^{.43}$ The total focus for Aviation's future operational capability concentrates on land component integration while joint air integration is strikingly absent. TRADOC Pam $525-80$ refers generically to a 
tailorability and modularity to interface information with joint, multinational, and interagency operations but precludes any consideration of a concept to integrate into joint air operations. The basis for USA Attack Aviation's forward doctrinal thinking lies exclusively with the land component commander regardless of unique adverse weather capability, and JFC requirements to apply paralysis across an enemy system.

\section{JOINT DOCTRINE REVIEW}

Does joint doctrine permit an avenue for integration of USA Attack Aviation into a joint air campaign? Joint Publications 3-0, Doctrine for Joint Operations, 1 February 1995, Joint Publication 5-0, Doctrine for Planning Joint Operations, 13 April 1995, and Joint Publication 3-56.1, Command and Control for Joint Air Operations, 14 November 1994 provide the guidelines for integrating USA Attack aviation into joint air operations. Joint air operations are defined as "air operations performed with the forces and capabilities made available by components in support of the Joint Force Commander's operation or campaign objectives, or in support of other joint components. ${ }^{n 44}$ General Ronald Fogleman, former Air Force Chief of Staff, defined air power as the "collection of unique capabilities that exploit and control the air and space media to gain a powerful advantage in time, mass, position, and awareness in pursuit of national security interests. ${ }^{n 45}$ This air power definition is appropriately void of service identity or sanctuary and represents the proper mindset for considering integration of all air forces in joint air operations.

Joint Publication 3-0 focuses on the strategic context of war, command relationships, and general guidelines for planning and integrating joint operations in Major Theater Wars (MTW) and 
Military Operations Other Than War (MOOTW). JP 3-0 highlights the need for strategic attack and interdiction to continue throughout sustained combat operations to "deny the enemy sanctuary or freedom of action. ${ }^{\mathrm{N6}}$ Air operations, in DESERT STORM were lauded for the relentless, lethal nature of the attacks against strategic, operational, and tactical objectives. Air operations employed to induce paralysis across the Iraqi system and minimized Iraqi ground resistance to land component objectives. Operation ALLIED FORCE attempted to conduct sustained operations, however adverse weather and concerns regarding collateral damage prevented continuous attacks against NATO objectives. ${ }^{47}$ JP 3-0 recognizes the decisiveness of offensive operations and stresses the need for early offensive operations against strategic objectives to render a quick and cost effective cessation of hostilities. ${ }^{48}$

Joint Publication 5-0 "covers the joint operation planning processes and concepts, reviews the relationship between joint operational planning and assessment, addresses deliberate and crisis action planning, and discusses strategic direction and integration.. ${ }^{49}$ JP 5-0 identifies some fundamentals of campaign plans, including unity of effort, operational focus, center of gravity determination and guidance for defeating them, organization of subordinate forces and designation of command relationships. ${ }^{50}$ Command relationships of subordinate forces in DESERT STORM were relatively clear with the JFACC maintaining operational control of Air Force units and tactical control of aircraft sorties made available by the Navy and Marine Corps. Although the initial Army Aviation air strike operated under joint control of the JFACC and the XVIII Corps, all other Army Attack aviation remained under the tactical control of the Army XVIII and VII Corps. ${ }^{51}$

Operation ALLIED FORCE command relationships with multi-national forces and USN air units included operational control while USAF-USA command relations were never completely worked out. ${ }^{52}$ The TF Hawk Air Liaison Officer (ALO) expressed frustration regarding the V Corps Deep Operations Coordination Cell (DOCC) assuming a lateral level with the Combined Air Operations Center (CAOC). ${ }^{53}$ The TF Hawk ALO considered the USA aviation assets tasked through the DOCC equal in command status with other air assets tasked through Wing Operations Centers (WOC). The implication of JP 5-0's planning guidance express a need for integration and clear identification of command relationships between subordinate commanders, without explicitly stating the requirement for integration of all military assets to accomplish JFC objectives. Although JP 5-0 sets the framework for the CINC and JFC to 
designate command relationships most effective to accomplish objectives, Operation ALLIED FORCE highlighted the need for some further refinements of the air integration process between air power components subordinate to the JFACC or CFACC, as appropriate.

Joint Publication 3-56.1 concentrates on the roles and responsibilities of the JFACC, the joint air operations planning process, the targeting and tasking process, and joint air operations center (JAOC) structure and function. JP 3-56.1 stresses the need for varying degrees of control and rules of engagement, as well as integration of fixed-and rotary-wing air assets of all components on the joint air tasking order (ATO). ${ }^{54}$ The JAOC conducts air component planning (including weaponeering), produces the joint ATO, and integrates other components into joint air operations. The JFACC staff, through the strategy section of Combat Plans, "allocates air capabilities and forces, and matches appropriate weapons against target vuinerabilities." ${ }^{55}$

Air forces are allocated matching aircraft against mission elements. Joint Publication $1-02, D O D$ Dictionary served as the source to define several of the aerospace mission elements used to clarify joint doctrine terminology. Air Interdiction (Al) are air operations conducted "to destroy, neutralize, or delay the enemy's military potential before it can be brought to bear effectively against friendly forces. Al is conducted at such distances from friendly forces that detailed integration of each air mission with the fire and movement of friendly forces is not required." ${ }^{56}$ Close Air Support (CAS) is "air action by fixed- and rotarywing aircraft against hostile targets which are in close proximity to friendly forces and which require detailed integration of each air mission with the fire and movement of those forces." After matching assets to missions and JFC approval of the joint ATO, the JFACC staff through the JAOC directs execution and deconflicts the air forces.

Operation DESERT STORM was the first operational use of the JFACC and JAOC construct. The GWAPS report assessed the employment of air resources as a unified effort that adequately integrated air forces. "The superabundance of Coalition aircraft, the absence of serious opposition in the air or effective attack against Coalition air bases relieved the JFACC and JFC of any harsh choices." ${ }^{58}$ In Operation ALLIED FORCE, the CFACC and CAOC construct was fully operational to prosecute the air 
campaign against Serbia. The joint ATO directed all NATO air forces and sought to match weapon systems and targets appropriately. Overall, the air campaign against Serbia forced Serbian ground forces to change military posture and withdraw from Kosovo, and applied pressure to President Milosevic to yield to NATO demands. ${ }^{59}$ JP 3-56.1 reinforces the requirement for JAOC flexibility and responsiveness to changing operational conditions and confirms the JFACC role in directing execution, retargeting missions, and responding to moving targets. ${ }^{60}$

\section{COMPLEMENTARY ASPECTS OF ARMY AND JOINT AIR DOCTRINE}

Based on this brief review of USA Service doctrine and Joint doctrinal planning and employment of air power, what complementary aspects encourage or permit full integration of USA Attack aviation into joint air operations? The USA and TRADOC doctrinal focus on depth and simultaneous attack are congruent with the Joint doctrinal focus on parallel attack and paralysis of an enemy system. The idea of using attack aviation throughout the width, height, and depth of the battle space is a congruent concept, when removed from the intended USA framework. The USA Attack Aviation employment methodology remains tied to the Army battlefield framework of deep, close, and rear operations compatible strictly with land warfare and force-on-force operations.

In joint air operations, the framework for employment of air power concentrates on mission elements, such as air interdiction (AI) and close air support (CAS), without regard to a specific distance or location from friendly forces. ${ }^{61}$ The USA Attack Aviation employment options including attacking massed enemy forces, dominating avenues of approach, conducting reconnaissance, and performing search and attack missions are compatible with the mission elements of air interdiction and strategic attack. When integrated within the joint air operations planning process, USA Attack Aviation employment options fit within the accepted joint air operation mission categories. The USA's assessment of Army Aviation's capability to self-deploy as an early entry asset complements the joint air doctrine for early, rapid offensive operations. Additionally, the TRADOC concept for USA Aviation's tailorability and modularity for information interface complements employment as a joint air asset. 


\section{DISPARATE ASPECTS OF ARMY AND JOINT AIR DOCTRINE}

The most compelling discontinuities between USA and Joint doctrine reside within the context of command relationships and the USA battle space framework. Additionally, command relationships such as supported and supporting command issues diverge doctrinally when considering USA Attack Aviation (a land maneuver element) as a member of a Task Force which is expected to integrate into joint air operations. Joint Force Quarterly reviewed the unity of command issue in DESERT STORM and suggests "unity of control of air operations vice unity of command was achieved, and was all that was required for a cohesive joint air campaign." ${ }^{\text {62 }}$ In Operation ALLIED FORCE, the same idea of unity of control of USA Attack Aviation was potentially a satisfactory compromise doctrinally and institutionally.

While unity of command (control) is a contentious issue, the battlefield construct is a much greater hurdle to leap in integrating USA Attack Aviation into joint air operations. USA Attack Aviation is handicapped by the doctrinal inflexibility to adapt to operations void of ground force-on-force conditions. The entire system for deconflicting units by boundaries or space, assigning missions and designating command relationships potentially changes with a shift in focus (for USA Attack Aviation) from deep and close attacks toward attacks aligned with joint air mission elements.

One additional input into the planning and employment construct of joint air operations resides within the curriculum of the Joint Doctrine Air Campaign Course (JDACC) taught at Maxwell AFB, Alabama. The mission statement of JDACC is "to prepare planners to serve on the staff of a Joint Forces Air Component Commander (JFACC) and to educate planners in the fundamental concepts, principles and doctrine required to develop and execute the air portion of a joint/combined campaign

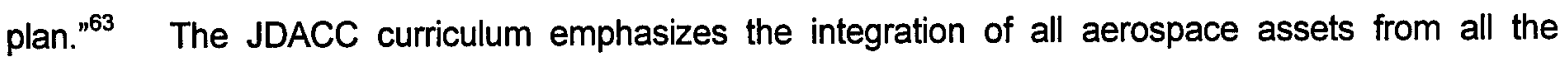
Components (JFLCC, JFMCC, JFSOCC, and JFACC). USA aviation, air defense, and theater missile defense are included to support JFACC mission area responsibilities of J-SEAD and duties as the Area Air Defense Commander (AADC) ${ }^{64}$ Lt Col Howard, the JDACC Course Director, considered USA Aviation as a legitimate air power asset when operational conditions permitted tactical control under the JFACC for accomplishing air objectives in support of the JFC's plan. ${ }^{65}$ The JDACC five-stage air campaign planning process is abbreviated in JP 3-56.1, Command and Control for Joint Air Operations. $^{66}$ 
Stage I identifies the USA Aviation assets availability and sets the framework for environmental factors which might highlight a requirement for specific capabilities (i.e., marginal weather-low ceilings, visibility, large enemy armor threat). Stage V, Joint Air and Space Operations Plan (JASOP) development combines the objectives, strategies, centers of gravity, force structure, and enemy/friendly courses of action constructed in Stages I-IV and applies the concept of phasing and validation to establish the air assets (numbers and types) required to fulfill theater objectives. Stage V, JASOP Development includes seven specific function categories:

1. Harmonizes the various air and space power functions.

2. Identifies desired effects, targets, and measures of effectiveness.

3. Identifies combat assessment criteria.

4. Prioritizes target sets.

5. Identifies level of effort against targets.

6. Identifies phasing and synchronization with other component plans.

7. Identifies force requirements to achieve objectives (types and numbers of platforms, sorties, and munitions). ${ }^{67}$

Within function seven, the match between USA Attack Aviation and the target set occurs. Based on JFLCC and JFACC staff coordination during function six, phasing and synchronization, JFACC planners would appropriately match USA Attack Aviation during an available window for employment. ${ }^{68}$ Although the JDACC curriculum stresses the need to evaluate the total capability of all the components air power assets, the faculty acknowledged the doctrinal differences or philosophies of employing USA Aviation outside of the JFLCC or ground construct previously identified above in the USA doctrinal publication review. The JDACC curriculum encourages full employment of all JFACC assets while allowing for additional capability to enhance more rapid accomplishment of air objectives through potential Marine Corps and Army Attack Aviation assets offered as excess air power. The air campaign planning process remains manageable for the planner by eliminating these potential excess air power assets until the final analysis in Stage IV of shortfalls in capability to accomplish specific air objectives. Although the air 
campaign planning process is better served by total integration of all air power assets in Stage I, the realities of opposing Service and Joint doctrinal constructs requires flexibility.

\section{CHAPTER 4 THE OPPOSING VIEWS OF INTEGRATING USA ATTACK AVIATION INTO JOINT AIR OPERATIONS}

I would argue at this point in history, that the air content of war is so high compared to the content of anything else that the principles that are most effective for air operations indeed need to be the general principles that define overall military operations. $^{69} \quad$ John A. Warden, Col, USAF (Retired)

Integrating USA Attack Aviation into Joint Air Operations encounters not only doctrinal barriers but also possibly institutional barriers. Policy statements, military periodicals, and interviews with aviators and military leaders in the USA, USAF, and in Joint Positions set the framework for identifying complementary and opposing factors for integrating all air power assets. General Jack Keane, USA Vice Chief of Staff declared his views during the 1999 Army Aviation Association of America's annual conference. Inside The Army, 17 May 1999 issue captured his contentious statements regarding placing USA Aviation systems under Joint control, namely the JFACC. He felt the current thinking on employing Army Apaches (as a supported ground component) in Kosovo was "dead wrong." GEN Keane voiced a need for joint control in an air campaign based on the range and distance Army Aviation achieves and the lack of communication connectivity. He perceived potential benefits of integrating USA Aviation under the JFACC through access to real-time intelligence sources (JSTARS, AWACS) increased safety through airspace control, and greater visibility for air protection (JSEAD). ${ }^{70}$ GEN Keane considered the level of command was elevated by a mindset tied back to difficulties of USA commanders serving as a supporting commander to the JFACC. He felt the Army Apaches were equivalent to a Wing Operations Center (WOC)-receives mission tasking through the joint ATO process and provides the assets to accomplish the effects desired, against the target assigned. GEN Keane appears to support the idea of Unity of Control of Air Assets proposed in the Summer 1993 issue of Joint Force Quarterly and believes "it's in the Army's own self-interest to properly support the joint ATO process." 
Within the same issue of Inside The Army, Major General John Riggs, commanding general of Ft. Carson, CO offered an opposing view to LT GEN Keane's ideas of USA Aviation systems under Joint Control. MAJ GEN Riggs acknowledged the "enhancements Joint Control brings to quick retasking, safety, and coordination." ${ }^{\prime 2} \mathrm{He}$, also voiced concern over the likely tension when air and ground campaign objectives clashed, and Army aviation was unavailable to "carry the day on a ground commander's conflict. ${ }^{73}$ MAJ GEN Riggs saw his first loyalty to the USA chain of command vice the JFC or CINC chain of command based on doctrinal and institutional requirements. Finally, MAJ GEN Riggs declared opposition to ATACMS and Apaches integration on the joint ATO during ground operations; he saw this action as a violation of the ground commander's boundaries or "envelope."

Defense Daily, May 26, 1999 issue entitled "Apache Role in Kosovo Illustrates Cracks in Joint Doctrine" identified some institutional disparities between what joint doctrine states and common practice. The reporters used a string of Air Force e-mail messages between the TF Hawk ALO and the USAF Doctrine Center Commander, coupled with retired USAF officer interviews to support their claims regarding the façade of jointness in military operations. The article points to "dissonance between the way each service trains and equips to fight and the mindsets that are instilled in warfighters by that experience." ${ }^{75}$ The fact Apaches appeared on the ATO for the first time under Task Force Hawk is cited to illustrate the lengthy delays in joint doctrine catching up with operational realities. The authors further cite technological shortfalls to integrating with support assets (JSTARS, AWACS, and JSEAD), inadequate air training and simulation tools, and ground-centric doctrine as cracks between operational practice and joint concepts. ${ }^{76}$

\section{USAF OFFICERS' OPINIONS REGARDING INTEGRATION}

The Combined Forces Air Component Commander (CFACC), LT GEN Mike Short visited the Command and General Staff College at Fort Leavenworth, Kansas in September 1999. He accommodated the USA and USAF SAMS officers with a special question and answer session regarding joint air operations in Kosovo. When questioned about the role of Army Attack Aviation in joint air operations, he spoke very candidly about his commitment to preserving the lives of all aircrew members and the requirement to employ forces when the conditions were appropriate for mission success. LT 
GEN Short indicated there were below the weather capabilities that TF Hawk was capable of employing with high risk, whereas the fixed-wing air assets were capable of attacking (once the weather lifted) these same targets with low risk. ${ }^{77}$ LT GEN Short commended the bravery and aggressiveness of the pilots, but felt the Apaches were simply too vulnerable to ground threats. He did not rule out the use of Army Attack Aviation in joint air operations when the environment (non-mountainous, low ground-to-air threat) was more conducive to helicopter employment. Doctrinally, LT GEN Short indicated the Apaches were not able to integrate with the CAOC air operations, but were only prepared to operate within a

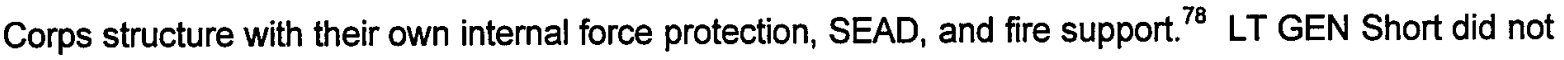
voice a requirement for Army Attack Aviation within the overarching Operation ALLIED FORCE combined forces air campaign plan.

Some insight into the reason for TF Hawk's deployment to support NATO's Air War Over Serbia was voiced in an interview with Air Force Magazine's senior editor, John A. Tirpak. LT GEN Short indicated GEN Clark, SACEUR repeatedly stressed his "no. 1 priority was the fielded forces in Kosovo and desired pilots to 'get down amongst them."'79 LT GEN Short, however, felt Serb forces in Kosovo "were a strategic dead end." ${ }^{\text {"O0 }}$ Armed with this belief, LT GEN Short indicated he did not feel compelled to allocate additional air power, including USA Attack Aviation against what he considered a futile effort. $^{81}$

In an interview with Colonel Chuck Greenwood, Director of the Air Force Doctrine Center (AFDC)-Ft Leavenworth, he discussed the operational environment immediately preceding V Corps involvement in Operation Allied Force and his observations on integrating USA Attack Aviation into joint air operations in the Air War Over Serbia. COL Greenwood was uniquely situated to view the total unfolding of V Corps train-up during the Battle Command Training Program (BCTP) WARFIGHTER exercise scheduled for 10-24 March 1999. He served as the JFACC to assist V Corps integration of air and ground operations and provide the operational-level air picture for joint targeting. COL Greenwood recalled this 
WARFIGHTER exercise was the first attempt at full integration of all USA air assets in the ATO, a painful but great learning experience for the V Corps soldiers who accomplished the feat. He speculated Lieutenant General Hendricks, V Corps Commander, anticipated employment of Apaches in Operation Allied Force and desired to minimize the learning curve resulting from a 'cold start' integration into a joint air operation. ${ }^{82}$

The WARFIGHTER exercise was canceled approximately halfway through the regularly scheduled scenario and the AFDC and BCTP personnel returned to $\mathrm{Ft}$ Leavenworth. On 25 March 1999, COL Greenwood was recalled to BCTP Headquarters and tasked to conduct rehearsal training for $V$ Corps (including the DOCC and $11^{\text {th }}$ Aviation Brigade) integration into the on-going NATO air operations. ${ }^{83}$ A small team of USA and USAF officers flew to the CAOC in Vicenza, Italy and V Corps Headquarters in Germany to gain a full understanding of the operational environment. "The combined AFDC-BCTP team gathered facts regarding $\mathrm{C} 2$, the ATO process, force availability and beddown, airspace procedures, rules of engagement (ROE), combined forces POCs, threat information, and the latest intelligence update." ${ }^{84}$ The team met the first week of April at the Warrior Prep Center (WPC) in Landstuhl, Germany to conduct a 3-day train-up exercise for V Corps. Over the next two weeks, COL Greenwood and other team members offered advice and briefed GEN Clark, LTGEN Short, and LTGEN Hendricks on several, separate occasions on the advantages, shortfalls and risks of TF Hawk employment in Operation Allied Force. 
Based on his experience in the V Corps WARFIGHTER and subsequent integration efforts with TF Hawk, COL Greenwood identified some doctrinal and institutional barriers for USA Attack Aviation's integration into joint air operations. The first barrier involved the lack of tactical doctrine to employ USA Attack Aviation as an air asset. Within the confines of USA tactical doctrine, COL Greenwood identified the friction between the doctrinal mandate to fight USA Attack Aviation in a combined arms environment (ground assets only) and the restrictive ROE eliminating the use of MLRS and ATACMS (due to collateral damage). ${ }^{85}$ Absent any tactical doctrine to employ USA Attack Aviation in an Air Interdiction (Al) or Strategic Attack (SA) role, TF Hawk was caught between operating in a hostile environment 'maneuvering on the fly' or sticking with inadequate 'over the shoulder' fighting doctrine. In Operation Allied Force, there were no ground troops to integrate 'over the shoulder' with to produce effects. COL Greenwood assessed the doctrine at the tactical level inadequate to meet the demands of the environment in the Air War Over Serbia.

The second barrier involved the lack of operational doctrine governing JFLCC responsibilities or relationships, and the accompanying operational-level staff responsibilities to integrate with the other components, such as the JFACC. COL Greenwood described the V Corps staff as "consumed at the tactical level of war, desperately attempting to operate co-equal with the $\mathrm{CAOC}$, and integrate at the operational level of war." ${ }^{\prime 86}$ TF Hawk illuminated the insurmountable difficulties for one staff to operate simultaneously at two levels of war--tactical and operational. 
Closely linked with doctrine, the third barrier concerns the multi-faceted institutional issue of training. COL Greenwood identified the training tools for simulating Apache results in BCTP WARFIGHTER exercises as completely unrealistic. He cites "zero terrain, guaranteed first shot targeting, and maximum range engagement ROE" as several examples which fail to simulate the complexities of air operations and preclude more detailed operational-level integration to increase aircraft survivability. ${ }^{87}$ The sense of invulnerability reinforced by the Combat Battlefield Simulation (CBS) fosters the idea that joint air operations integration is unnecessary since USA Attack Aviation is best left to "fly alone, unafraid, and communication (comm) out. ${ }^{188} \mathrm{COL}$ Greenwood voiced concerns regarding the lack of routine joint training with C2, JSEAD and ISR platforms, such as the AWACS, EA6B, J-STARS, and RC-135 RIVET JOINT aircraft. Without consistent joint training, TF Hawk aviators were ill prepared to communicate, respond to ground threats, or fully comprehend the air power capabilities resident in the air component to improve their survivability and effectiveness. COL Greenwood stressed "the Apaches were not ready to meet the perceived public expectation to fight like fixedwing, fighter squadrons and must be given time to train and build currency for night operations in a theater air operation. ${ }^{189}$

In his final comments regarding USA Attack Aviation integration into joint air operations, COL Greenwood believed that within certain environments (i.e., nonmountainous terrain) a rotary-wing asset is the most effective weapon system to employ. He felt there was always an increased risk to rotary-wing assets due to low altitude ground threats, but considered integration at the operational-level possible 
only after sufficient training and doctrinal changes. In the final analysis, $\mathrm{COL}$ Greenwood believed public expectation of minimal losses does not preclude the integration of USA Attack Aviation however the importance of the risk assessment and commander's guidance to employ these assets wisely remains imperative. ${ }^{90}$

Major Todd Serres, Fighter Operations expert in the Air Force Element of the USA Command and General Staff College shared some observations from his experiences as an aviator and staff officer working Joint Air Interdiction and Joint Close Air Support issues. He identified a multifaceted role for USA Attack Aviation in joint air operations, including SA, AI, CSAR, armed reconnaissance, and CAS. ${ }^{91}$

MAJ Serres viewed doctrine as the top barrier to integration. He considered USA Attack Aviation, as the most significant firepower asset the Division Commander owned, and concluded the centralized control of these assets under the JFACC was an unacceptable outcome for the ground commander. ${ }^{92}$ The joint air doctrine tenet of Centralized Control with Decentralized Execution was directly at odds with the USA decentralized control of Attack Aviation. Major Serres felt USA Attack Aviation doctrine permitted only two general operational modes for attack helicopters, "a fire support arm of a maneuver force or as an integral maneuver unit."

Major John Sepanski, an air operations expert assigned to the Battle Command Training Program (BCTP), shared his observations formed during four Division WARFIGHTERS and several years of flying operations in PACOM, EUCOM, and CENTCOM. He believed USA Attack Aviation should integrate with joint air operations in a CAS, AI, and SA role. Major Sepanski indicated doctrinally and through the BCTP exercises, the USA maintained a tactical focus for Attack Aviation, 
often using rotary-wing assets as a 911 force.$^{94}$ Additionally, the USA doctrine failed to recognize or address task-organizing assets on an operational level, outside the Corps command structure. Major Sepanski experienced repeatedly the great opposition at Division level to launch deep attacks-Division planning staffs indicated deep operations were in "the too hard to do box."." Institutionally, he addressed the mindset of the USA Aviators to 'go along with the Army program and avoid thinking joint', the resistance of BDE Commanders to tackle issues outside their lane, and the perception that the world revolves around the USA Area of Operations. On a one-onone basis, Major Sepanski felt the USA Aviators understood the general concepts of joint air integration, potential survivability benefits, and the mechanics of the information required to gain access to the ATO. Otherwise as a corporate body, "the Division focus for the BCTP WARFIGHTERS on the close fight and attrition warfare only managed to integrate USA combined arms, with merely a superficial attempt to integrate joint air assets. ${ }^{196}$ Major Sepanski identified three avenues to dissolve the doctrinal and institutional barriers:

1. Develop USA doctrine to perform the CAS role and then initiate a training program.

2. Educate officers at joint level to integrate (refine CGSC core curriculum).

3. Senior Level Commanders (Corps and Division) must adopt a joint vision. 97

USA OFFICERS' OPINIONS REGARDING INTEGRATION 
Major General Richard Cody, the Apache pilot who led opening strikes in Operation DESERT STORM and author of the TF Hawk after-action report evaluated USA preparation for Kosovo operations. GEN Cody testified before the House Military Readiness Subcommittee and stated, "the Apache pilots deployed to Albania lacked what he considered necessary training, over 500 hours of flight experience (65 percent below this level) and proficiency in night-vision goggle flight operations (no pilots qualified in the copilot seat). ${ }^{.98}$ Train-up fatalities from the second Apache helicopter crash raised questions about the Task Force's readiness to commence operations immediately in Kosovo.

Major General Anthony R. Jones, Commanding General of the USA Aviation Center and Lieutenant Colonel Michael L. McGary, Chief, Aviation Center Doctrine Division co-authored an electronic response on Army Aviation's integration into joint air operations. They acknowledged "Army Aviation's role as an integrated member to the joint team in a supported or supporting role and identified 'independent operations by an aviation element, supporting a joint force, such as a JFACC as the exception rather than the norm, but clearly possible." ${ }^{\prime 99}$ GEN Jones and LCOL McGary assessed the top three challenges to effective integration of Army Aviation into joint air operations as institutional training, joint operational training exercises, and joint and Army doctrine. They considered several solutions such as greater "schoolhouse" level instruction on joint force integration and increased joint training opportunities for army aviation units in "Flag" exercises, Roving Sands and Global Patriot. Finally, doctrinal initiatives to better define aviation's role and operational 
guidance for Army's forces in the joint environment were seen as GEN Jones and LCOL McGary's best methods to face challenges to joint integration.

In the November 1999 USA Pre-Command Course, two new battalion commanders offered their opinions regarding integration of USA Attack Aviation into joint air operations. One of the officers was an Apache pilot and the other was a Special Operations pilot. Each officer responded to four questions:

1. Do you feel Army Attack Aviation has a role in joint air operations? If yes, what role? If no, why?

2. What are the top three barriers you perceive to integrating Army Attack Aviation in joint air operations?

3. Do you view the source of barriers to integrating USA Attack Aviation into joint air operations as doctrinally or institutionally-based?

4. Can these barriers be resolved? If yes, how?

LCOL Stephen Ingalls, an Apache pilot and new Battalion Commander expressed his opinion regarding the barriers to USA Attack Aviation integration. He felt Army Attack Aviation's role in joint air operations resided exclusively with support to the Army's ground component of the joint force. Within the context of USA Attack Aviation operating as an entity without a ground force (or with a small force), a combination of doctrine and training was the number one barrier. He felt the doctrinal and training architecture for Attack Aviation failed to address operations outside "a 
larger decide/detect architecture..100 There simply was no structure or context for USA Attack Aviation to conduct deep operations outside the context of a Corps DOCC to integrate C2, Fires, and Force Protection. When questioned whether a fully-funded Red Flag exercise was an acceptable answer to at least the training architecture issue, he stressed that the focus must be on the National Training Center (NTC) and Brigade-level exercises to develop greater skills in combined arms fighting. ${ }^{101}$ The second barrier was a cultural issue, which the interviewee felt was fundamental to the long-term stability of the Army Aviation Branch. He believed "Army Aviation does not want to broaden challenges to air/ground integration by taking a step in the other direction." ${ }^{102}$ The other direction being a separate force in support of the JFACC. He discussed the great efforts by Army Aviation enthusiasts to gain total acceptance since 1983 as a full maneuver arm, and he viewed any efforts to detract from the combined arms focus as a dangerous road. Finally, the interviewee identified the barriers as insurmountable and culturally disastrous due to insufficient training resources (ammunition and budget shortfalls) and time to master and focus on extensive Mission Essential Task List (METL) requirements to support his number one priority, the ground commander. ${ }^{103}$

Lieutenant Colonel John Buss, a USA Special Operations Pilot and new Battalion Commander with the $160^{\text {th }}$ SOAR provided some insight into the barriers affecting USA Attack Aviation's integration into joint air operations. LCOL Buss identified the top three barriers to integration of Army Attack Aviation as training and doctrine, experience of Army Aviation force, and limited numbers of assets (afraid of piecemeal approach to employment). ${ }^{104}$ He considered the source of the barriers to 
be both institutional and doctrinal. Institutionally, the perception of loss of some control to the JFACC and doctrinally, insufficient focus on air operations prevents integration. LCOL Buss highlighted "the focus of all the qualification courses and professional military education is solely on the ground battle, the formal combat and command education fails to train or educate Army Aviators to think and operate in an air environment.."105 In order to dissolve the barriers, LCOL Buss recommended habitual interaction, doctrinal changes, joint training, and operations as a joint force. $^{106}$

Lieutenant Colonel (select) Scott McConnell, currently a student at the School of Advanced Military Studies was assigned as the Task Force S-3 Stabilization Forces (SFOR), Bosnia-Herzegovina and worked extensively with the CAOC to integrate air and ground operations. LCOL McConnell identified neutralizing threat ADA systems as one potential role for USA Attack Aviation in joint air operations. He cited TF Normandy in Operation DESERT STORM as an example of Attack Aviation as a supporting force to the JFACC. LCOL McConnell identified the institutional perception and emotion surrounding subordination of USA Aviation to the JFACC as a recipe for total loss to the Army. Although, he felt training Army aviators on the use of the ATO as a situational awareness tool would maximize the air effort, integration with the DOCC timelines could prove irreconcilable. He cited "the doctrinal and tactical flexibility of USA Attack Aviation to accept target changes as late as six hours from strike time (well inside the ATO cycle) as a barrier to integrating in joint air operations." ${ }^{107}$ Institutionally, LCOL McConnell felt the Army Aviation Branch could not decide on the right path for Attack Aviation to pursue--the combined arms 
approach only or a combination of combined arms and joint air integration. He referenced the Spring 1999 Army Aviation Association of America Conference where the VCSA, GEN Keane was the lone vocal proponent encouraging the integration of Army Aviation on the ATO. LCOL McConnell's advice on breaking the barriers resides with the 'senior leadership buy-in' to the concept and a corresponding change in doctrine. ${ }^{108}$

\section{SUMMARY}

The top barriers to integration identified through interviews and military statements by USA and USAF officers are both institutional and doctrinal. The institutional barriers surround the issues of trust (misperception of intentions), view of command relationships, allocation of training resources and lack of joint air operations focus in professional military education programs. The primary doctrinal barrier was the lack of an operational framework for Army Attack Aviation to integrate with the joint air operations center outside of the Corps structure. Many of the officers agreed some form of integration is helpful and necessary with the proper training and doctrine in place to facilitate success.

\section{CHAPTER 5 FINAL ANALYSIS AND INTEGRATION RECOMMENDATIONS}

The Commander in Chief or Joint Force Commander's objectives in a theater set the operational framework for joint operations whether the responsibility resides 
within the Joint Force Land Component Commander's Area of Operations or the Joint Force Air Component Commander's theater responsibilities. As the central commander responsible for achieving air objectives the JFACC or CFACC, as appropriate and the Staff must fully understand the capabilities and limitations of all available aerospace power assets and plan for effective employment of all appropriate air power assets to fully achieve theater objectives.

In order for the JFACC Staff to understand the complexities and employment details of USA Attack Aviation and other Service component air assets, the military education process must broaden beyond joint professional military education courses to core intermediate service school curriculum, Service advanced course curriculum, and unit Tactics courses. For example, the Core Tactics Curriculum at the USA Command and General Staff College allocates approximately eight hours of instruction out of over one hundred and fifty total hours for integrating Air Operations. The introductory Tactics lesson states the requirement to integrate with other components and with the exception of short lessons on the other components, actual practical application of the joint integration principles rarely occurs. In the final course war game, the total focus revolves around a close fight, force-on-force attrition battle with little to no integration of air power assets permitted with the ground plan. This initial Division level, 'student-designed' planning exercise serves as another reinforcement of the Army false impression that air operations should never be integrated into a ground plan. Despite the evidence of Operation DESERT STORM, where history demonstrated the requirement for linking air component and ground component objectives to achieve theater objectives, the professional military 
educational system has not fully adjusted the curriculum to acknowledge the interdependency of the forces. The institutional barriers among the USA and USAF officers which foster a lack of knowledge regarding each component's capabilities can be resolved over time through a concerted effort to overhaul the intermediate service school curriculums.

Once the professional military education system is energized, the disparities between Service doctrine and Joint doctrine must be addressed and mitigated, as soon as practical. The USA operational doctrine is the first hurdle to tackle to ensure the duties and responsibilities of the Joint Force Land Component Commander (JFLCC) and accompanying operational-level Staff are delineated. The Joint Force Air Component Commander and Staff system could serve as a general guideline to assist in structuring operational-level doctrine and staff processes. Currently the School of Advanced Military Studies (SAMS) at Ft Leavenworth, KS plans to partner with the School of Advanced Warfare Studies (SAWS) at Quantico, VA to mold the creative efforts of Army and Marine Corps officers to lay the framework for the JFLCC structure. Along with establishing the structure for the JFLCC, a joint-designed SAMS-SAWS JFLCC training program could alleviate any drain on the Army Corps Staffs or Marine Expeditionary Forces (MEF) Staffs to design, teach, and evaluate Land Component Commander Staffs. This joint effort will deliver a framework for the long required land component operational doctrine under which tactical level doctrine may expand toward a theater focus.

Within the framework of tactical level doctrine, USA Attack Aviation doctrine requires an overhaul to address some of the doctrinal shortfalls highlighted by Task 
Force Hawk's preparation for Operation ALLIED FORCE. Command relationship issues and operational-level integration constructs should be delineated in the JFLCC doctrine and training. USA Attack Aviation doctrine should link into operational doctrine through the identification of air mission elements, the Branch considers applicable to Attack Aviation, incorporation of the ATO process into staff planning constructs, and expansion of the combined arms support infrastructure to include aerospace capabilities. Tackling these three areas requires time, perseverance, and top-level support from the Aviation Branch proponent and Corps Commanders down through the Advanced Schools to the Attack Helicopter Battalions and Companies. The doctrinal changes and ideas must be debated, refined, and incorporated in the training regimen of unit-level, BCTP, and NTC WARFIGHTER Exercises.

Institutionally, the training regimen within the USA must evaluate the changes operational-level doctrine brings to the ground component and address any shortfalls within the existing training apparatus. One possible preliminary shortfall could be the simulation capability for air power assets, including all fixed-wing and rotary-wing aircraft. In order to fully train tactical forces to integrate tactical action with operational objectives, a starting point might possibly be more realistic air power effects to encourage a deeper level of staff interaction and integration of joint capabilities. The time, space, combat power relationships of the tactical-level ground component commander might expand and become less pronounced. For example, planning a Division-level river crossing under the full integration of joint capabilities (increased destruction of enemy capability threatening the area of operation) greatly 
reduces the risk to the same Division force conducting a Division-level river crossing with organic assets. Although, the equation for the tactical-level staff includes more assets to synchronize, the threat is reduced allowing greater freedom of maneuver and greater focus on ground objectives to meet theater objectives.

Another series of training issues at the tactical level for USA Attack Aviation focuses on air mindedness. Air mindedness includes operating as an air maneuver force, refining tactics in day-time and night-time operations, developing partnerships with fixed-wing fighters, electronic warfare platforms, and command and control platforms to improve effectiveness and survivability as a member of the aerospace community. Participating in joint-funded bilateral training exercises and full-scale Red Flag Exercises provides an opportunity for doctrine and practical mastery to mesh and form the basis for a new institutional culture to replace the 'alone, unafraid, and communication out' mindset. Based on the feedback of several USA officers, time to allocate for training is another issue which might preclude participation in Red Flag Exercises and would require a greater emphasis on local training to close the gap on interoperability and coordination issues. Perhaps earmarking specific Aviation Brigades or Battalions at Echelons above Division to integrate at the joint level would balance the concerns for training allocation time with doctrinal and practical mastery on operations in the joint air environment. Developing and fostering air mindedness is a lengthy process, requiring perhaps five to ten years to filter down from the Army Chief of Staff level through the Aviation Branch and onto the Tactical level where the Attack Helicopter Battalions employ. 


\section{CONCLUSION}

Integrating USA Attack Aviation into joint air operations is the right idea given the proper time to define the doctrine, educate the force, and train the staffs and aviators. Just as the process to accept USA Attack Aviation as a ground maneuver force required overcoming extreme cultural and doctrinal barriers, the next step in the evolution of the role of USA Attack Aviation is capable of overcoming similar barriers.

The Joint Force Land Component operational level doctrine must be designed, debated, refined, and fielded. Land Component Operational-level staffs require education and training to fully understand the complexities and intricacies of theater level integration, in this case with the Air Component. The training construct of the USA must expand to incorporate joint requirements and assist in the development of ground forces capable of fighting in support of aerospace forces. Operations DESERT STORM and ALLIED FORCE provided a snapshot in time of the integration of USA Attack Aviation into joint air operations.

Future research on the Joint Force Land Component Commander construct and accompanying Staff element are suggested to address issues not covered by this monograph. Additionally, future study on the mechanics of integrating the Joint Air Operations Center and the Joint Land Operations Center processes should better define the construct for subordinate staffs to support. Finally, the USA Aviation Branch should nominate topics for research on emerging air tactics development to expedite an air-focused, tactics training curriculum for integration into joint air operations. 


\section{SELECTED BIBLIOGRAPHY}

Air Liaison Officer (ALO) e-mail traffic. April 1999. "Army Aviation and AF Integration"

Contains e-mail traffic initiated by the ALO for Task Force Hawk in Kosovo describing doctrinal and institutional barriers for integration of Army Aviation into the ATO.

Atkinson, David and Hunter Keeter. "Apache Role in Kosovo Illustrates Cracks in Joint Doctrine." Defense Daily. May 26, 1999, 6.

Baker, Caleb. "Blue Print That Changes Army Aviation." Army 44 no. 4 (April 1994): 26-30.

Baltimore Sun. "Army Hunts For Answers As Apaches Fail In Kosovo." July 16, 1999:

Available on-line at http://ebird.dtic.mil/Jul1999/e19990716army.htm.

Bingham, Price T., Lt Col (Ret). "Theater Warfare, Movement, and Airpower."

Airpower Journal 12 no. 2 9Summer 1998): 15-26.

Blumentritt, John W., Maj. 'Will Airpower, Specifically Helicopters, Replace Tanks in

2010?" Armor 107 n. 5 (September-October 1998): 8-12.

LCOL John Buss, USA), Student at the USA Pre-Commander's Course. Interview with author on 19 November 1999, Ft Leavenworth, KS.

Butler, Howard K. "Army Aviation Policy 1945 to 1950." USA Aviation Digest (September - October 1990): 34-39.

Burke, Charles M., Col and Presgraves, Donald C., Capt. "U.S. Army Operational Concept for Aviation." USA Aviation Digest 5 (September-October 1993): 7-13.

Carpenter, P. Mason, Major (USAF). The Effect of Command Relationships on Joint Operations in the Gulf War. June 1994. School of Advanced Aerospace Studies, Maxwell AFB, AL: AU Press. Available on-line at http://www.maxwwell.af.mil/au/saas/studrsch/; accessed 3 September 1999.

Cohen, William S. Secretary of Defense and Chairman, Joint Chiefs of Staff Henry H.

Shelton. Joint Statement on the Kosovo After Action Review. Joint Statement 
Before the Senate Armed Services committee, October 14, 1999. Accessed on-line by DefenseLink News Release on 23 October 1999: 1-24.

Cohen, William S. Secretary of Defense and Chairman, Joint Chiefs of Staff Henry H.

Shelton. DOD Press Statement on Operation ALLIED FORCE, June 10, 1999. Accessed transcript on-line by DefenseLink News Release on 3 September 1999: 1-18.

Cordesman, Anthony $\mathrm{H}$. The Lessons and Non-Lessons of the NATO Air and Missile

Campaign in Kosovo. Available on-line at http://www.csis.org/Kosovo; accessed 24 September 1999: 1-181.

Drew, Dennis M., Col. "Airpower Imperative: Hard Truths For an Uncertain World." Strategic Review 19 no. 2 (Spring 1991): 24-31.

Drake, Jessica. "Task Force Hawk Critique May Speed key Apache Upgrades." Aerospace Daily (July 21, 1999): available online from http://ebird.dtic.mil/Jul1999/e19990721task.htm.

Erskine, J. W., Squadron Leader (RAF). "Air Power and Joint Warfare-Time to Reflect." The Royal Air Force Air Power Review 2 no. 2 (Summer 1999): 130-133.

Field Manual 100-5. Operations. Washington D. C.: Headquarters Department of the Army. June 1993.

Field Manual 1-112. Attack Helicopter Operations. Washington D. C.: Headquarters Department of the Army. 2 April 1997.

Field Manual 100-103. Army Airspace Command and Control in a Combat Zone. Washington D. C.: Headquarters Department of the Army. October 1987.

Fogleman, Ronald R., GEN. "Advantage USA: Airpower and Asymmetric Force Strategy." Air Power History 43 no. 2 (Summer 1996): 4-13.

Fontenot, Greg, COL (USA, RET). Former Director of Battle Command Training Program (BCTP) and military advisor to $V$ Corps during operations in support of Air War Over Serbia. Response to interview questions by author on 28 November 1999, Ft Leavenworth, KS.

Forshag, Russell, S. "Culminating points in aviation operations." USA Aviation Digest (January-February 1990): 36-42.

Gehring, Stephen P. From The Fulda Gap To Kuwait: U.S. Army, Europe and the Gulf 
War. Washington D. C.: U.S. Government Printing Office, 1998.

Goodman, Glenn W., Jr. "Army Aviation's Stellar Plans Hamstrung by Budget Shortfalls." Armed Forces Journal International 130 no. 9 (April 1993): 37-38.

Grayson, Eugene H. "Where do we (Army Aviation) Go From Here?" USA Aviation Digest (March-April 1992): 44-47.

Greenwood, Chuck, COL (USAF). Director of the Air Force Doctrine Center, Ft. Leavenworth, KS. Trip Report on Apache Rehearsal and SACEUR Tasking (26 March - 10 April 1999): 1-6.

Greenwood, Chuck, COL (USAF). Director of the Air Force Doctrine Center, Ft. Leavenworth, KS. Interview with author on November 10, 1999, Ft Leavenworth, KS.

Griffith, Ronald H., LT GEN (USA). "Mission Accomplished-In Full." United States Naval Institute Proceedings (August 1993): 63-65. Volume 119. (In response to questions regarding the absence of air power during the last 24 hours of the ground campaign, in spite of exceptional weather, LTGEN Griffith indicated he did not see a need for air power. He felt most of the modern equipment was destroyed and what little remained in the KTO could be easily controlled by the capable ground forces. (p. 64)

Grossman, Elaine M. "Kosovo War Tactics For Strategy Void, Expert Says." Inside The Pentagon (July 1, 1999): 1 . Available online at http://ebird.dtic.mil/Jul1999/ s19990701war.htm. Interview with retired USAF Col. John Warden.

Gulf War Air Power Survey (GWAPS) Volume I: Planning and Command and Control. Washington, D. C.: U.S. Government Printing Office, 1993.

Halbleib, Richard C., Lt Col and Earley, Mark M., Lt Col. 'Three-dimensional Battlespace: The U.S. Army Must Transition its Forces into Advanced Airfighting Platforms." Armed Forces Journal International 136 no. 4 (December 1998): 50-51.

Hallion, Richard P. "Air Power Today and Tomorrow: A Post-Gulf War View." RUSI Journal 139 no 5 (October 1994): 23-29.

Hancock, Rick D., Maj. "Division Attack Helicopter Operations." USA Aviation Digest (September-October 1989): 60-64.

Harrison, Benjamin L., MGEN. "Aviation: A Branch Decision Revisited." Army 41 no. 2 (January 1991): 22-25.

Hollis, Patrecia S. "Making the Most of Air Power, Interview With Gen. Ronald R. Fogleman, Chief of Staff of the Air Force." Field Artillery (September-October 1996): 3-5.

Ingalls, Stephen. LCOL, USA. Student at the USA Pre-Commander's Course. 
Interview with author on 12 November 1999, Ft Leavenworth, KS.

JDACC. Joint Doctrine Air Campaign Course. Attended 19-29 October 1999. College of Aerospace Doctrine Research and Education (CADRE). Maxwell AFB, AL.

JDACC Handbook. Air Campaign Planning Handbook. Maxwell AFB, AL:

CADRE, July 1998, 1-90.

Joint Doctrine Encyclopedia. Washington D. C.: U.S. Government Printing Office, 16 July 1997.

Joint Publication 1-02. Department of Defense Dictionary of Military and Associated Terms. Washington D. C.: Joint Staff, 23 March 1994 as amended through 29 June 1999, 1-624.

Joint Publication 3-0. Doctrine for Joint Operations. Washington D. C.: Joint Staff, 1 February 1995.

Joint Publication 3-56.1. Command and Control for Joint Air Operations. Washington D. C.: Joint Staff, 14 November 1994.

Joint Publication 5-0. Doctrine for Planning Joint Operations. Washington D. C.: Joint Staff, 13 April 1995.

Jones, Anthony R (MGEN) and LCOL Michael L. McGary. Commanding General, USA Aviation Center and Chief, Doctrine Division USA Aviation Center response to e-mail interview questions by the author on 27 December 1999. Fort Rucker, AL.

Kroesen, Frederick J., GEN (Ret). "Would You Really Rather Have Airpower?" Army 49 no. 1 (January 1999): 9.

Lambeth, Benjamin S. "Technology Revolution in Air Warfare." Survival 39 no. 1 (Spring 1997): 65-83.

Leibstone, Marvin. "U.S. Army Aviation: The Gulf and Beyond." Military Technology 15 no. 4 (April 1991): 25-27.

Lembke, R. Keith, Capt. "Vision is Clear (Preparing Army Aviation for the Future Battlefield)." USA Aviation Digest (July-August 1994): 10-15.

Manza, John D., Capt. "Helicopterborne Operations in a Major Regional Contingency." Marine Corps Gazette 79 no. 10 (October 1995): 21-24.

McConnell, Scott. LCOL (S), USA. Student at the School of Advanced Military Studies.

(Conducted operations in Bosnia integrating USA Aviation with joint air operations in the Combined Air Operations Center at Vicenza, Italy). Interview with author on 8 November 1999, Ft Leavenworth, KS.

Mueller, Karl. "Strategies of Coercion: Denial, Punishment, and the Future of Air 
Power." Security Studies 4 no. 3 (Spring 1998): 182-228.

Pelczynski, Anthony S., Capt and Cho Choon Ho, Capt (ROK). "Attack Helicopter Operations in the Combined Environment." USA Aviation Digest 4 (July-August 1993): $29-30$.

Pendleton, Blaine, CW3. "Seven Crucial Elements to Achieve Combat Readiness." USA Aviation Digest (January-February 1994): 15-19.

Petrosky, Daniel J., COL and Major Marshall T. Hillard. "An Aviation Brigade Goes To War." USA Aviation Digest (September-October 1991): 44-65.

Pulley, John. "Making of a Precision Strike Force: Preparations to Attack the Serbs Demonstrate the Latest Air-Warfare Strategy." Air Force Times 59 no. 130 (November 2 1998): 10-14.

Reimer, Dennis J., GEN. "Army-Where We Are Going and How We Are Getting There!" USA Aviation Digest (March-April 1992): 7-9.

Robinson, David J., MGEN and Burke, Charles M., Col. "Fighting Maneuver and Fires in the Third Dimension." Field Artillery (April 1993): 11-14.

Robinson, David J., MGEN. "Army Aviation's Role in the Future Defined Through Battle Labs." USA Aviation Digest (November-December 1992): 1-3.

Ropelewski, Robert R. "Threat and Budget Changes Imperil Army Aviation Plan." Armed Forces Journal International 127 (April 1990): 50-51.

Schnell, Warren and McDonald, Eugene. "Anytime, Any place (Army Aviation Lessons Learned In Operation Desert Shield)." USA Aviation Digest (January-February 1991): 6-7.

Sepanski, John. MAJ, USAF. Staff Officer with the USA Battle Command Training Program (BCTP). Interview with author on 8 November 1999, Ft Leavenworth, KS.

Serres, Todd. MAJ, USAF. Staff Officer in the Air Force Element, USA Command \& General Staff College. Interview with author on 15 November 1999, Ft Leavenworth, KS.

Short, Michael C. Lt Gen, USAF. September 9, 1999 talk (question and answer session) with the School of Advanced Military Studies and Air Force Officers at Fort Leavenworth, Kansas.

Stephens, Alan Dr. "High Noon of Air Power." The Royal Air Force Air Power Review 2 no. 2 (Summer 1999): 3-23.

Tirpak, John A. "Shifting Patterns of Air Warfare (Air Force Leaders Put Change in Perspective at AFA'S Air Warfare Symposium)." Air Force Magazine 80 no. 4 (April 1997): 22-26. 
Tirpak, John A. "Short's View of the Air Campaign." Air Force Magazine 82 no. 9 (September 1999): 43-47.

TRADOC Pamphlet 525-5. FORCE XXI OPERATIONS: A Concept for the Evolution Of Full-Dimensional Operations for the Strategic Army of the Early Twenty-

First Century. Fort Monroe, VA: Headquarters, Army Training and Doctrine Command, 1 August 1994: 1-1-4-11.

TRADOC Pamphlet 525-80. Army Aviation Warfighting Concept of Operations. Fort Monroe, VA: Headquarters, Army Training and Doctrine Command, 3 August 1998.

Vozzo, Pete, Capt. "Capabilities and Expectations (for Army Aviation)." USA Aviation Digest (July-August 1992): 26-28.

Warden, John A., III Col. The Air Campaign: Planning For Combat. Washington D. C.: National Defense University Press, 1988.

Warden, John A., III Col. "Enemy as a System." Airpower Journal 9 no. 1 (Spring 1995): 40-55.

Warden, John A., III. "Success in Modern War: A Response to Robert Pape's Bombing To Win." Security Studies 4 n. 2 (Winter 1998): 172-190.

Welch, William G., LCOL (USA). "Notes from the BCE-Observations on Joint Combat Operations at Echelons Above Corps." Field Artillery (June 1992): 16-21. (Senior Plans Officer for the 1st BCE [Battlefield Coordination element], XVIII ABN Corps, Fort Bragg, NC. Served as Senior Plans officer deployed for DESERT STORM)

Winnefeld, James A. and Dana J. Johnson. "Unity of Control: Joint Air Operations in Gulf." Joint Force Quarterly 1 (Summer 1993): 88-99.

Winograd, Erin Q. "Next Vice Chief Argues Aviation Assets Must Be Put Under Joint Control." Inside The Army (May 17, 1999): 1-2.

\footnotetext{
1 Jessica Drake, "Task Force Hawk Critique May Speed Key Apache Upgrades," Aerospace Daily, 21 July 1999.

${ }^{2}$ Erin Q. Winograd, "Next Vice Chief Argues Aviation Assets Must Be Put Under Joint Control," Inside the Army, 17 May 1999, 2.

${ }^{3}$ Dr. Eliot A. Cohen, ed., Gulf War Air Power Survey Planning and Command and Control, (Washington D. C.: U.S. Government Printing Office, 1993), vol. 1, 37-39.

${ }^{4}$ Michael R. Gordon and General Bernard E. Trainor, The General's War, (Boston: Little, Brown \& Company, 1995), 472-473.

${ }^{5}$ Air Liaison Officer (ALO) e-mail traffic, April 1999, "Army Aviation and Air Force Integration," Contains e-mail traffic initiated by the ALO for Task Force Hawk in Albania describing
} 
doctrinal and institutional barriers to integrating USA Aviation into the Air Tasking Order and operations with the Combined Air Operations Center-Vicenza, IT.

"Baltimore Sun, "Army Hunts For Answers As Apaches Fail In Kosovo," 16 July 1999.

${ }^{7}$ Baltimore Sun, "Army Hunts For Answers As Apaches Fail In Kosovo," 16 July 1999.

${ }^{8}$ Joint Publication 1-02, Joint Electronic Library, 16 July 1997, 359.

${ }^{9}$ Dr. Eliot A. Cohen, ed., Gulf War Air Power Survey Planning and Command and Control, (Washington D. C.: U.S. Government Printing Office, 1993), vol. 1, 175.

${ }^{10} \mathrm{Dr}$. Thomas A. Keaney and Dr. Eliot A. Cohen, ed., Gulf War Air Power Survey. Summary

Report, (Washington D. C.: U.S. Government Printing Office, 1993), 40.

${ }^{11}$ Dr. Eliot A. Cohen, ed., Gulf War Air Power Survey Operations and Effects and

Effectiveness, (Washington D. C.: U.S. Government Printing Office, 1993), vol. 2, 120.

${ }^{12}$ Dr. Eliot A. Cohen, ed., Gulf War Air Power Survey Operations and Effects and

Effectiveness, (Washington D. C.: U.S. Government Printing Office, 1993), vol. 2, 260.

${ }^{13} \mathrm{Dr}$. Thomas A. Keaney and Dr. Eliot A. Cohen, ed., Gulf War Air Power Survey Summary

Report, (Washington D. C.: U.S. Government Printing Office, 1993), 112.

${ }^{14}$ Mason P. Carpenter, Major (USAF), "The Effect of Command Relationships on Joint

Operations in the Gulf War," (MMAS, diss., School of Advanced Aerospace Studies, Maxwell

AFB, AL, 1994), 90.

${ }^{15}$ John A. Warden III, COL (USAF), The Air Campaign: Planning For Combat, (Washington

D. C.: National Defense University Press, 1988), 157.

${ }^{16}$ Stephen P. Gehring, From The Fulda Gap To Kuwait: U.S. Army, Europe and the Gulf War, (Washington D. C.: U.S. Government Printing Office, 1998), 97.

${ }^{17}$ Stephen P. Gehring, From The Fulda Gap To Kuwait: U.S. Army, Europe and the Gulf War, (Washington D. C.: U.S. Government Printing Office, 1998), 8.

${ }^{18}$ Stephen P. Gehring, From The Fulda Gap To Kuwait: U.S. Army, Europe and the Gulf War, (Washington D. C.: U.S. Government Printing Office, 1998), 25.

${ }^{19}$ Field Manual (FM) 100-5, Operations, (Washington D. C.: Headquarters Department of the Army, June 1993), 6-14.

${ }^{20}$ Field Manual (FM) 100-5, Operations, (Washington D. C.: Headquarters Department of the Army, June 1993), 6-14.

${ }^{21}$ Field Manual (FM) 100-5, Operations, (Washington D. C.: Headquarters Department of the Army, June 1993), 6-14.

${ }^{22}$ Field Manual (FM) 100-5, Operations, (Washington D. C.: Headquarters Department of the Army, June 1993), 6-15.

${ }^{23}$ Dr. Thomas A. Keaney and Dr. Eliot A. Cohen, ed., Gulf War Air Power Survey Summary Report, (Washington D. C.: U.S. Government Printing Office, 1993), 111.

${ }^{24}$ COL Daniel J. Petrosky and MAJ Marshal T. Hillard (USA), "An Aviation Brigade Goes To War," USA Aviation Digest, September-October 1991, 56.

${ }^{25}$ LT GEN Ronald H. Griffith (USA), "Mission Accomplished-In Full." United States Naval Institute Proceedings, August 1993, 64. (In response of questions regarding the absence of air power during the last $\mathbf{2 4}$ hours of the ground campaign, in spite of exceptional weather, LT GEN Griffith indicated he did not see a need for air power. He felt most of the modern equipment was destroyed and what little remained in the KTO could be easily controlled by the capable ground forces.)

${ }^{26}$ John A. Warden III, COL (USAF), The Air Campaign: Planning For Combat, (Washington D. C.: National Defense University Press, 1988), 167.

${ }^{27}$ Dr. Eliot A. Cohen, ed., Gulf War Air Power Survey Operations and Effects and

Effectiveness, (Washington D. C.: U.S. Government Printing Office, 1993), vol. 2, 291. 
${ }^{28}$ Secretary of Defense William S. Cohen and Chairman, Joint Chiefs of Staff Henry $\mathrm{H}$. Shelton, Joint Statement on the Kosovo After Action Review, Senate Armed Services Committee Hearing, October 14, 1999.

${ }^{29}$ Secretary of Defense William S. Cohen and Chairman, Joint Chiefs of Staff Henry $\mathrm{H}$. Shelton, DOD Press Conference on June 10, 1999 at the Pentagon, transcript available online through Defense Link News.

${ }^{30}$ Admiral James O. Ellis, Commander, Joint Task Force NOBLE ANVIL during Operation ALLIED FORCE, After Action Review Briefing entitled "A View From The Top," undated briefing distributed through the Professional Military Education schools in September 1999. (Admiral Ellis states the brief "is an attempt to give a senior Commander's unique perspectives and personal opinions, thoughts on how the next JFC can fight his campaign even better, and a springboard for open and frank discussion).

${ }^{31}$ LT GEN Michael C. Short, Combined Forces Air Component Commander for Operation ALLIED FORCE, September 9, 1999 talk with the School of Advanced Military Studies and the U.S. Air Force Officers assigned at Ft Leavenworth, KS.

${ }^{32}$ LT GEN Michael C. Short, Combined Forces Air Component Commander for Operation ALLIED FORCE, September 9, 1999 talk with the School of Advanced Military Studies and the U.S. Air Force Officers assigned at Ft Leavenworth, KS.

${ }^{33}$ Anthony $\mathrm{H}$. Cordesman, an independent researcher on the Air War Over Serbia, The Lessons and Non-Lessons of the NATO Air and Missile Campaign in Kosovo. Avail-able on-line at http://www.csis.org/Kosovo; accessed 24 September 1999; 19.

${ }^{34}$ Anthony $\mathrm{H}$. Cordesman, an independent researcher on the Air War Over Serbia, The

Lessons and Non-Lessons of the NATO Air and Missile Campaign in Kosovo. Avail-able on-line at http://www.csis.org/Kosovo; accessed 24 September 1999; 24.

${ }^{35}$ LT GEN Michael C. Short, Combined Forces Air Component Commander for Operation

ALLIED FORCE, September 9, 1999 talk with the School of Advanced Military Studies and the U.S. Air Force Officers assigned at Ft Leavenworth, KS.

${ }^{36}$ Air Liaison Officer (ALO) e-mail traffic, April 1999, "Army Aviation and Air Force Integration," Contains e-mail traffic initiated by the ALO for Task Force Hawk in Albania describing doctrinal and institutional barriers to integrating USA Aviation into the Air Tasking Order and operations with the Combined Air Operations Center-Vicenza, IT.

${ }^{37}$ Greenwood, Chuck, COL (USAF), Director of the Air Force Doctrine Center, Ft Leavenworth, KS. Interview with author on November 10, 1999, Ft Leavenworth, KS.

${ }^{38}$ Field Manual 1-112, Attack Helicopter Operations, (Washington D. C.: Headquarters Department of the Army, 2 April 1997), 1-1.

${ }^{39}$ Field Manual 1-112, Attack Helicopter Operations, (Washington D. C.: Headquarters Department of the Army, 2 April 1997), 1-3.

${ }^{40}$ Field Manual 1-112, Attack Helicopter Operations, (Washington D. C.: Headquarters Department of the Army, 2 April 1997), 1-13.

${ }^{41}$ COL Greg Fontenot (RET), Former Director of Battle Command Training Program (BCTP) and military advisor to $V$ Corps during operations in support of Air War Over Serbia.

Response to interview questions by author on 28 November 1999, Ft Leavenworth, KS. (He identifies the height of the 9,000 foot peaks and hostile ground fire from long-range rockets and artillery as the main contributors to a tactical environment not conducive for effective Attack Aviation employment)

42 TRADOC Pamphlet 525-5, FORCE XXI OPERATIONS: A Concept for the Evolution

Of Full-Dimensional Operations for the Strategic Army of the Early Twenty-First Century, (Fort Monroe, VA: Headquarters, Army Training and Doctrine Command, 1 August 1994), 310.

${ }^{43}$ TRADOC Pamphlet 525-80, Army Aviation Warfighting Concept of Operations, (Fort 
Monroe, VA: Headquarters, Army Training and Doctrine Command, 3 August 1994), 3.

44 Joint Publication 3-56.1, Command and Control for Joint Air Operations, (Washington D. C.: Joint Staff, 14 November 1994), 1-1.

${ }^{45}$ GEN Ronald R. Fogleman, USAF Chief of Staff, "Advantage USA: Air power and

Asymmetric Force Strategy," Air Power History 43 no. 2 (Summer 1996), 11-12.

${ }^{46}$ Joint Publication 3-0, Doctrine for Joint Operations, (Washington D. C.: Joint Staff, 1

February 1995), IV-7.

${ }^{47}$ Anthony H. Cordesman, an independent researcher on the Air War Over Serbia, The

Lessons and Non-Lessons of the NATO Air and Missile Campaign in Kosovo. Avail-able on-line at http://www.csis.org/Kosovo; accessed 24 September 1999; 19.

${ }^{48}$ Joint Publication 3-0, Doctrine for Joint Operations, (Washington D. C.: Joint Staff, 1

February 1995), IV-7.

${ }^{49}$ Joint Publication 5-0, Doctrine for Planning Joint Operations, (Washington D. C.: Joint

Staff, 13 April 1995), vii.

${ }_{50}$ Joint Publication 5-0, Doctrine for Planning Joint Operations, (Washington D. C.: Joint

Staff, 13 April 1995), II-20.

${ }^{51}$ Dr. Thomas A. Keaney and Dr. Eliot A. Cohen, ed., Gulf War Air Power Survey Summary

Report, (Washington D. C.: U.S. Government Printing Office, 1993), 146.

${ }_{52}$ COL Chuck Greenwood, (USAF), Director of the Air Force Doctrine Center, Ft

Leavenworth, KS. Interview with author on November 10, 1999, Ft Leavenworth, KS.

${ }^{53}$ Air Liaison Officer (ALO) e-mail traffic, April 1999, "Army Aviation and Air Force

Integration," Contains e-mail traffic initiated by the ALO for Task Force Hawk in Albania

describing doctrinal and institutional barriers to integrating USA Aviation into the Air Tasking

Order and operations with the Combined Air Operations Center-Vicenza, IT.

${ }^{54}$ Joint Publication 3-56.1, Command and Control for Joint Air Operations, (Washington D.

C.: Joint Staff, 14 November 1994), vii.

${ }_{55}$ Joint Publication 3-56.1, Command and Control for Joint Air Operations, (Washington D.

C.: Joint Staff, 14 November 1994), IV-2.

${ }_{56}$ Joint Publication 1-02, DOD Dictionary of Military and Associated Terms, (Washington D.

C.: Joint Staff, 23 March 1994 as amended through 29 June 1999, 35.

${ }^{57}$ Joint Publication 1-02, DOD Dictionary of Military and Associated Terms, (Washington D.

C.: Joint Staff, 23 March 1994 as amended through 29 June 1999, 93.

${ }^{58}$ Dr. Thomas A. Keaney and Dr. Eliot A. Cohen, ed., Gulf War Air Power Survey Summary

Report, (Washington D. C.: U.S. Government Printing Office, 1993), 160.

${ }^{59}$ Secretary of Defense William S. Cohen and Chairman, Joint Chiefs of Staff Henry $\mathrm{H}$.

Shelton, Joint Statement on the Kosovo After Action Review, Senate Armed Services

Committee Hearing, October 14, 1999.

60 Joint Publication 3-56.1, Command and Control for Joint Air Operations, (Washington D.

C.: Joint Staff, 14 November 1994), IV-11.

61 Joint Publication 3-56.1, Command and Control for Joint Air Operations, (Washington D.

C.: Joint Staff, 14 November 1994), IV-11.

62 James A. Winnefeld and Dana J. Johnson, "Unity of Control: Joint Air Operations in Gulf," Joint Force Quarterly 1 (Summer 1993), 99.

${ }^{63}$ JDACC. Joint Doctrine Air Campaign Course. Attended 19-29 October 1999. College of Aerospace Doctrine Research and Education (CADRE). Maxwell AFB, AL.

${ }_{64}$ Joint Publication 3-56.1, Command and Control for Joint Air Operations, (Washington D.

C.: Joint Staff, 14 November 1994), II-3.

${ }_{65}$ JDACC. Joint Doctrine Air Campaign Course. Attended 19-29 October 1999. College of

Aerospace Doctrine Research and Education (CADRE). Maxwell AFB, AL. 
${ }^{66}$ Joint Publication 3-56.1, Command and Control for Joint Air Operations, (Washington D. C.: Joint Staff, 14 November 1994), ix-X.

${ }^{67}$ JDACC Handbook, Air Campaign Planning Handbook, Maxwell AFB, AL:

CADRE, July 1998, 33-40.

${ }^{68}$ JDACC. Joint Doctrine Air Campaign Course. Attended 19-29 October 1999. College of Aerospace Doctrine Research and Education (CADRE). Maxwell AFB, AL.

${ }^{69}$ Elaine M. Grossman, "Kosovo War Tactics For Strategy Void, Expert Says," Inside The

Pentagon (July 1, 1999), 1. Available online at http://ebird.dtic.mil/Jul1999/

s19990701war.htm. Interview with retired USAF Col. John Warden.

${ }^{70}$ Erin Q. Winograd, "Next Vice Chief Argues Aviation Assets Must Be Put Under Joint Control," Inside The Army (May 17, 1999), 1.

${ }^{71}$ Erin Q. Winograd, "Next Vice Chief Argues Aviation Assets Must Be Put Under Joint Control," Inside The Army (May 17, 1999), 1.

${ }^{72}$ Erin Q. Winograd, "Next Vice Chief Argues Aviation Assets Must Be Put Under Joint Control," Inside The Army (May 17, 1999), 1.

${ }^{73}$ Erin Q. Winograd, "Next Vice Chief Argues Aviation Assets Must Be Put Under Joint Control," Inside The Army (May 17, 1999), 1.

${ }^{74}$ Erin Q. Winograd, "Next Vice Chief Argues Aviation Assets Must Be Put Under Joint Control," Inside The Army (May 17, 1999), 1.

${ }_{75}^{75}$ David Atkinson and Hunter Keeter, "Apache Role in Kosovo Illustrates Cracks in Joint Doctrine" Defense Daily, May 26, 1999, 6.

${ }^{76}$ David Atkinson and Hunter Keeter, "Apache Role in Kosovo Illustrates Cracks in Joint Doctrine" Defense Daily, May 26, 1999, 6.

${ }^{77}$ LT GEN Michael C. Short, Combined Forces Air Component Commander for Operation ALLIED FORCE, September 9, 1999 talk with the School of Advanced Military Studies and the U.S. Air Force Officers assigned at Ft Leavenworth, KS.

${ }^{78}$ LT GEN Michael C. Short, Combined Forces Air Component Commander for Operation ALLIED FORCE, September 9, 1999 talk with the School of Advanced Military Studies and the U.S. Air Force Officers assigned at Ft Leavenworth, KS.

79 John A Tirpak, Senior Editor of Air Force Magazine, "Short's View of the Air Campaign." Air Force Magazine, (September 1999), 43.

${ }^{80}$ John A Tirpak, Senior Editor of Air Force Magazine, "Short's View of the Air Campaign." Air Force Magazine, (September 1999), 43.

${ }^{81}$ LT GEN Michael C. Short, Combined Forces Air Component Commander for Operation ALLIED FORCE, September 9, 1999 talk with the School of Advanced Military Studies and the U.S. Air Force Officers assigned at Ft Leavenworth, KS.

${ }^{82} \mathrm{COL}$ Chuck Greenwood, (USAF), Director of the Air Force Doctrine Center, $\mathrm{Ft}$ Leavenworth, KS. Interview with author on November 10, 1999, Ft Leavenworth, KS.

${ }^{83} \mathrm{COL}$ Chuck Greenwood, (USAF). Director of the Air Force Doctrine Center, Ft. Leavenworth, KS. Trip Report on Apache Rehearsal and SACEUR Tasking ( 26 March - 10 April 1999): 1.

${ }^{84}$ COL Chuck Greenwood, (USAF). Director of the Air Force Doctrine Center, Ft. Leavenworth, KS. Trip Report on Apache Rehearsal and SACEUR Tasking (26 March - 10 April 1999): 1.

${ }^{85} \mathrm{COL}$ Chuck Greenwood, (USAF), Director of the Air Force Doctrine Center, $\mathrm{Ft}$ Leavenworth, KS. Interview with author on November 10, 1999, Ft Leavenworth, KS.

${ }^{86}$ COL Chuck Greenwood, (USAF), Director of the Air Force Doctrine Center, Ft Leavenworth, KS. Interview with author on November 10, 1999, Ft Leavenworth, KS.

${ }^{87}$ COL Chuck Greenwood, (USAF), Director of the Air Force Doctrine Center, Ft

Leavenworth, KS. Interview with author on November 10, 1999, Ft Leavenworth, KS. 
${ }^{88}$ COL Chuck Greenwood, (USAF), Director of the Air Force Doctrine Center, Ft

Leavenworth, KS. Interview with author on November 10, 1999, Ft Leavenworth, KS.

${ }^{89} \mathrm{COL}$ Chuck Greenwood, (USAF). Director of the Air Force Doctrine Center, Ft.

Leavenworth, KS. Trip Report on Apache Rehearsal and SACEUR Tasking (26 March - 10

April 1999): 6.

${ }^{90} \mathrm{COL}$ Chuck Greenwood, (USAF), Director of the Air Force Doctrine Center, Ft

Leavenworth, KS. Interview with author on November 10, 1999, Ft Leavenworth, KS.

${ }^{91}$ MAJ Todd Serres, (USAF), Staff Officer in the Air Force Element, USA Command \& General Staff College. Interview with author on 15 November 1999, Ft Leavenworth, KS.

${ }^{92}$ MAJ Todd Serres, (USAF), Staff Officer in the Air Force Element, USA Command \& General Staff College. Interview with author on 15 November 1999, Ft Leavenworth, KS.

${ }^{93}$ MAJ Todd Serres, (USAF), Staff Officer in the Air Force Element, USA Command \&

General Staff College. Interview with author on 15 November 1999, Ft Leavenworth, KS.

${ }^{94}$ MAJ John Sepanski, (USAF), Staff Officer with the USA Battle Command Training Program (BCTP), Interview with author on 8 November 1999, Ft Leavenworth, KS.

${ }^{95}$ MAJ John Sepanski, (USAF), Staff Officer with the USA Battle Command Training Program (BCTP), Interview with author on 8 November 1999, Ft Leavenworth, KS.

${ }^{96}$ MAJ John Sepanski, (USAF), Staff Officer with the USA Battle Command Training Program (BCTP), Interview with author on 8 November 1999, Ft Leavenworth, KS.

${ }^{97}$ MAJ John Sepanski, (USAF), Staff Officer with the USA Battle Command Training Program (BCTP), Interview with author on 8 November 1999, Ft Leavenworth, KS.

${ }_{98}$ Baltimore Sun, "Army Hunts For Answers As Apaches Fail In Kosovo," 16 July 1999.

${ }^{99}$ MGEN Anthony R. Jones and LCOL Michael L. McGary, Commanding General of the USA

Aviation Center and Chief, USA Aviation Doctrine Center. Response to author's e-mail questions on 27 December 1999, Ft Rucker, AL.

${ }^{100}$ LCOL Stephen Ingalls, (USA), Student at the USA Pre-Commander's Course. Interview with author on 12 November 1999, Ft Leavenworth, KS.

${ }^{101}$ LCOL Stephen Ingalls, (USA), Student at the USA Pre-Commander's Course. Interview with author on 12 November 1999, Ft Leavenworth, KS.

${ }^{102}$ LCOL Stephen Ingalls, (USA), Student at the USA Pre-Commander's Course. Interview with author on 12 November 1999, Ft Leavenworth, KS.

${ }^{103}$ LCOL Stephen Ingalls, (USA), Student at the USA Pre-Commander's Course. Interview with author on 12 November 1999, Ft Leavenworth, KS.

${ }^{104}$ LCOL John Buss, USA), Student at the USA Pre-Commander's Course. Interview with author on 19 November 1999, Ft Leavenworth, KS.

${ }^{105}$ LCOL John Buss, USA), Student at the USA Pre-Commander's Course. Interview with author on 19 November 1999, Ft Leavenworth, KS.

${ }^{106}$ LCOL John Buss, USA), Student at the USA Pre-Commander's Course. Interview with author on 19 November 1999, Ft Leavenworth, KS.

${ }^{107}$ LCOL (S) Scott McConnell, (USA), Student at the School of Advanced Military Studies. (Conducted operations in Bosnia integrating USA Aviation with joint air operations in the Combined Air Operations Center at Vicenza, Italy). Interview with author on 8 November 1999, Ft Leavenworth, KS.

${ }^{108}$ LCOL (S) Scott McConnell, (USA), Student at the School of Advanced Military Studies. (Conducted operations in Bosnia integrating USA Aviation with joint air operations in the Combined Air Operations Center at Vincent, Italy). Interview with author on 8 November 1999, Ft Leavenworth, KS. 
